\title{
Growth and development rates of the copepod Calanus finmarchicus reared in the laboratory
}

\author{
Robert G. Campbell ${ }^{1, *}$, Melissa M. Wagner ${ }^{1}$, Gregory J. Teegarden ${ }^{2}$, \\ Carla A. Boudreau ${ }^{1}$, Edward G. Durbin ${ }^{1}$ \\ ${ }^{1}$ Graduate School of Oceanography, University of Rhode Island, Narragansett, Rhode Island 02882-1197, USA \\ ${ }^{2}$ Bowdoin College, 6700 College Station, Brunswick, Maine 04011, USA
}

\begin{abstract}
Development rates, nitrogen- and carbon-specific growth rates, size, and condition were determined for the copepod Calanus finmarchicus reared at 3 temperatures $\left(4,8\right.$, and $\left.12^{\circ} \mathrm{C}\right)$ at non-limiting food concentrations and 2 limiting food concentrations at $8^{\circ} \mathrm{C}$ in the laboratory. Development rates were equiproportional, but not isochronal. Naupliar stage durations were similar, except for non-feeding stages, which were of short duration, and the first feeding stage, which was prolonged, while copepodite stage durations increased with increasing stage of development. Under limiting food concentrations at $8^{\circ} \mathrm{C}$, development rates were prolonged but similar relative patterns in stage durations were observed. Body size (length and weight) was inversely related to temperature and positively related to food concentration. Condition measurements were not affected by temperature, but were positively related to food concentration. Growth rates increased with increasing temperature and increased asymptotically with increasing food concentration. At high food concentrations, growth rates of naupliar stages were high (except for individuals molting from the final naupliar stage to the first copepodite stage, in which growth rates were depressed), while growth of copepodites decreased with increasing stage of development. Neither nitrogen nor carbon growth rates, the former a proxy for structural growth, were exponential over the entire life cycle, but rather sigmoidal. Carbon-specific growth rates were greater than nitrogen-specific growth rates, and this difference increased with increasing stage of development, reflecting an augmentation in lipid deposition in the older stages. However, nitrogen and carbon growth rates were more similar under foodlimited conditions. Based on this study, we recommend that secondary production rates of Calanus finmarchicus and possibly other lipid-storing copepods not be estimated from egg production measurements alone, as has been suggested for other species of copepods, because growth, including structural growth, is not equivalent for all stages.
\end{abstract}

KEY WORDS: Calanus finmarchicus $\cdot$ Development $\cdot$ Growth $\cdot$ Temperature $\cdot$ Food concentration Resale or republication not permitted without written consent of the publisher

\section{INTRODUCTION}

Calanus finmarchicus is one of the most abundant species of copepod in the North Atlantic (Conover 1988), and is an important link between phytoplankton and higher trophic levels, particularly larval fish (Runge 1988). It is presently a target species in several large interdisciplinary programs. On Georges Bank, it is a target species in the US GLOBEC Northwest Atlantic Georges Bank Study, which seeks to describe

\footnotetext{
*E-mail: campbell@gso.uri.edu
}

biological and physical factors that control its abundance there. C. finmarchicus is also the target species for the TASC (Trans-Atlantic Study of Calanus) program, whereby European investigators are seeking to understand the physical and biological processes that control its population dynamics in the NE Atlantic. Information on the development and growth rates of $C$. finmarchicus as a function of both food and temperature is needed in these programs to help interpret field measurements and for use in models.

A number of previous studies have reared Calanus finmarchicus through part or all of its life cycle (Crawshay 1913, Lebour 1916, Mathews 1966, Corkett et al. 
1986, Tande 1988, Marcus \& Alatalo 1989). The early studies were mainly descriptive, and only the study by Corkett et al. (1986) attempted to describe development quantitatively. Corkett et al. (1986) reared $C$. finmarchicus at a series of different temperatures ( 2 to $10^{\circ} \mathrm{C}$ ) at high food concentrations on a mixture of small phytoplankters, and observed the development times during the copepodite stages. Because their observations were incomplete, they assumed equiproportional development, i.e. that each developmental stage occupied the same time relative to other stages at constant temperature (Corkett 1984). They used parameters from the Belehrádek (1935) equation for egg duration as a function of temperature to construct curves for development times of each copepodite stage as a function of temperature. At present, there is essentially no information available for naupliar development times or for growth rates of any stages. Here we report results of a series of experiments in which we determined the development times, sizes and growth rates of $C$. finmarchicus reared in the laboratory at 3 temperatures $\left(4,8\right.$ and $\left.12^{\circ} \mathrm{C}\right)$ at high food concentrations, and at 2 limiting food concentrations at $8^{\circ} \mathrm{C}$.

\section{METHODS}

Calanus finmarchicus culture conditions. The experiment was conducted from June through October 1996. Copepodites of Calanus finmarchicus were collected between Cape Cod and Georges Bank from the Northwestern Atlantic during May 1996. About 10000 Stage 4 and 5 copepodites were sorted and raised to adults at $8^{\circ} \mathrm{C}$ in $100 \mathrm{l}$ tanks on a mixed-phytoplankton diet (Gymnodinium sanguinium and Heterocapsa triquetra fed ad lib). These adults then were subdivided into several groups that were acclimated for $2 \mathrm{~d}$ to the experimental temperatures of 4,8 , and $12^{\circ} \mathrm{C}$. To begin the experiments, batches of eggs were collected from the adult females over $24 \mathrm{~h}$ periods during early June 1996. About 7500 eggs from each batch were placed in duplicate $100 \mathrm{l}$ tanks for each experimental condition. Duplicates were established at each of the 3 tempera-

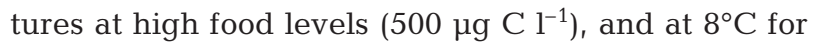
medium (50 $\left.\mu \mathrm{g} \mathrm{C}^{-1}\right)$ and low $\left(25 \mu \mathrm{g} \mathrm{C}^{-1}\right)$ food levels. These were the target concentrations for each treatment; the actual mean concentrations were somewhat less due to grazing (see Table 1). The experimental tanks were aerated gently to provide mixing and were illuminated dimly from above with cool-white fluorescent lights on a light cycle of 12:12 h light:dark (L:D). The density of copepods was reduced in all tanks over the course of the experiment from 100 to $200 \mathrm{l}^{-1}$ for early naupliar stages to less than $5 \mathrm{l}^{-1}$ for late copepodite stages by removing copepods during sampling.
Copepods were raised from egg to reproducing adults in all treatment tanks except Tank L1 (low food) at $8^{\circ} \mathrm{C}$. This tank was terminated after the copepods reached C3 because very few remained, and consequently food concentrations were not controlled well enough due to the high algal growth rates. At the time of termination, similar stage proportions were present in both replicate tanks (percentage $\geq$ Stage C 3 : Tank 1, 50\%; Tank $2,44 \%$ ). Populations of $C$. finmarchicus in the $4^{\circ} \mathrm{C}$ tanks reached maturity in fall 1996; the final tank was terminated in October 1996.

Food sources. The copepods in each treatment were maintained on a mixed diet that, in terms of carbon, was comprised of $90 \%$ phytoplankton (equal carbon concentrations of Gymnodinium sanguinium, Heterocapsa triquetra, and Tetraselmis sp.) and $10 \%$ of a heterotrophic dinoflagellate (Oxyrrhis marina). Food concentration in each experimental vessel was determined from microscopic counts each day, and food levels were adjusted daily (high food) or twice daily (medium and low food) to maintain appropriate cell concentrations. All cultures of phytoplankton were maintained in exponential growth using a semicontinuous batch-culture technique by diluting daily with fresh, sterile, culture media ( $\mathrm{f} / 2$, Guillard \& Ryther 1962). O. marina was fed $H$. triquetra in a similar manner to the culture-media additions in order to maintain exponential growth. New cultures were started regularly to replace older cultures so that detritus and hence bacteria would not build up and change the food quality for the copepods. The size of the culturing vessels was dependent on the growth rate of the organisms as well as the quantity required by the copepods. Tetraselmis $s p$. and $O$. marina were grown in 81 polycarbonate bottles, $H$. triquetra in 201 bottles, and G. sanguinium in 2001 transparent, plastic cylinders (K-tubes). Cultures were grown under cool-white fluorescent lights on a 12:12 h L:D cycle at $16^{\circ} \mathrm{C}$ and were cooled to appropriate temperatures before being fed to the copepods.

During the course of the experiment, the mix of phytoplankton food that was fed to the copepods was adjusted several times. When the copepods reached the early copepodite stages, Tetraselmis sp. was removed from the diet in all tanks because it was not being grazed as heavily as the larger dinoflagellates and appeared to have caused some water-quality problems that involved more frequent water changes. After the 12 and $8^{\circ} \mathrm{C}$ experiments had ended and when copepodites were molting into $\mathrm{C} 5$ in the $4^{\circ} \mathrm{C}$ experiments, we were not able to maintain Gymnodinium sanguinium at sufficient densities, so it was removed from the diet. In each case, the remaining species of phytoplankton were increased to maintain the total concentrations of carbon. 
Sampling. Stage abundances for the populations of Calanus finmarchicus in the experimental vessels were determined from samples of 50 to 100 individuals. Copepods were collected by gently mixing the tanks and removing the necessary volume of water with a beaker or by towing an appropriately sized sieve from the bottom to the surface when the density of copepods was reduced. Frequency of sampling varied by stage, experimental temperature, and food level ${ }_{i}$ copepods were sampled at least 4 times during each molt and regularly between molts. During the early stages of the experiment, it was necessary to sample the tanks at $8 \mathrm{~h}$ intervals. These samples were preserved in buffered formaldehyde for later enumeration.

Additional samples were taken from each tank at roughly the midpoint of each stage (N6 and all copepodite stages) or early in development (Stage N3) for measuring nitrogen $(\mathrm{N})$, carbon $(\mathrm{C})$, length, and RNA:DNA. Egg diameter and egg $\mathrm{N}$ and $\mathrm{C}$ were also determined for each temperature treatment. The RNA:DNA results are reported elsewhere (Wagner et al. 2001, this issue). Changes in $\mathrm{N}$ and $\mathrm{C}$ between stages were used to calculate growth rates. Since all copepods collected in each sample were grouped to determine their $\mathrm{N}$ and $\mathrm{C}$ content (except for stage $\mathrm{C} 5$ and above where individuals could be measured) the sample did not always consist of a single stage. In the high-food treatments, the cohorts remained together and the sample almost always consisted of $>95 \%$ of the dominant stage. In contrast, in the medium- and low-food treatments, several stages were usually present in the sample because of spreading of cohorts.

Copepods for chemical analysis were anesthetized with MS-222 solution, and images from a subsample were recorded with a video system for later length measurements. For length measurements, the prosome length of copepodites was measured, but only the cephalosome (the anterior rigid portion of the carapace) of the nauplii was measured. This region was chosen because it was difficult and time consuming to position nauplii properly to obtain an accurate total length measurement. Cephalosome lengths of nauplii were converted to total lengths by multiplying by the appropriate stage-specific conversion factors that have been empirically determined in our laboratory. Nauplii and eggs for $\mathrm{C}$ and $\mathrm{N}$ analysis were collected by pipette and gently filtered onto $13 \mathrm{~mm}$ glass-fiber filters that had been precombusted at $400^{\circ} \mathrm{C}$ for $1 \mathrm{~h}$. Copepodites were picked up with forceps and placed in pre-cleaned tin boats. A minimum of 3 replicates and 30 individuals in total of the grouped stages (eggs to $\mathrm{C} 4$ ) were measured, with the number within each replicate being determined by the sensitivity of the $\mathrm{CN}$ analyzer $(15 \mu \mathrm{g} \mathrm{N})$. For $\mathrm{C} 5$ and adults, 30 individuals were measured. The samples were dried at $60^{\circ} \mathrm{C}$ in an oven for $24 \mathrm{~h}$ and then placed in a desiccator until analyzed with a Carlo Erba NA 1500 carbon/nitrogen analyzer. Lengths were measured with an imageanalysis system (NIH Image).

Egg production. In the high food treatments at 4 and $8^{\circ} \mathrm{C}$, egg production rates were determined for females collected from the tanks at the end of the experiment following the methods described in Runge \& Roff (2000). Insufficient females remained in the $12^{\circ} \mathrm{C}$ tanks at the conclusion of the experiment to determine egg production rates accurately. Individual females were incubated for $24 \mathrm{~h}$ in $25 \mathrm{ml}$ petri dishes filled with filtered seawater. The dishes were checked every $8 \mathrm{~h}$ and any eggs observed were counted and removed to reduce cannibalism. The number of eggs produced by each female in the $24 \mathrm{~h}$ incubation was summed to provide the individual egg production rate (EPR), while the population EPR was the mean EPR of all females, including those that did not spawn. The spawning frequency was the proportion of females that spawned per day.

Data analysis. Size and condition: In determining temperature-weight $(\mathrm{N}, \mathrm{C})$ relationships for Stages N3 to $\mathrm{C} 5$, we corrected for the age within stage of the copepods at the time of sampling, since the samples were usually taken a little earlier or later than the midpoint. For this, the midpoint of each stage was determined from the actual stage duration data for each tank and the weight at the midpoint was exponentially interpolated from the weight measurements that had been made on either side of the midpoint. For eggs and adults, the actual weights were used. For the temperature-length relationships, no corrections for sampling time were made since length did not change very much within a stage.

Condition factor $(C F)$, or weight per unit volume, is a measure of a copepod's nutritional status, higher values indicating better condition (Durbin et al. 1995). Carbon (CCF) and nitrogen (NCF) condition factors were calculated from the equation:

$$
C F=W L^{-3}
$$

where $W=$ weight $(\mathrm{N}$ or $\mathrm{C}$ in $\mu \mathrm{g})$ and $L=$ prosome length $(\mathrm{mm})$.

Development: The median development time (MDT), the time from the midpoint of the egg-laying period to when $50 \%$ of the copepods have reached a given stage, was estimated from stage frequency data (Landry 1975, Peterson \& Painting 1990). This was accomplished by plotting the cumulative proportion of each stage against time, and determining the time when $50 \%$ of the copepods have reached that stage by least-squares linear regression performed on the linear portion of each curve (excluding the tails, $<10$ and $>90 \%$ ). 'Stage duration' was the time between the MDT of 2 successive stages. 
Belehrádek's (1935) temperature function was used to describe development times under high food conditions as a function of temperature following the method of Corkett et al. (1986). Development time (D) for any one stage is given by:

$$
D=\mathrm{a}(T-\alpha)^{\mathrm{b}}
$$

where $\mathrm{a}, \mathrm{b}$, and $\alpha$ are constants and $T$ is the temperature. The value for $b$ was taken to be -2.05 from Corkett et al. (1986), who found this to be the mean for 11 species of copepods. This function was then fitted to our egg development times to provide estimates of a and $\alpha$. For the remaining stages, the value of $\alpha$ determined from the egg development time fit was used, and a was the only fitted parameter. Initially, we fitted all 3 parameters to our egg development time data, but the fit was only slightly better than that obtained using Corkett et al.'s (1986) value for $b\left(r^{2}=0.9916\right.$ vs 0.9913$)$. In addition, the average fit for all stages using our estimates of $b$ and $\alpha$ or their $b$ and our estimate of $\alpha$ was the same $\left(r^{2}=0.9974\right)$. Therefore, we chose to use the value for b from Corkett et al. (1986) to be consistent with previous work and reduce the number of fitted parameters.

Development time variability (DTV): The true variance in development times or stage durations can only be obtained by making measurements on individual copepods. However, an estimate of the variability can be obtained by closely following a cohort of copepods that are similar in age and whose age limits are known through several stages, and measure the time from when they start molting to when they complete molting for each stage. We define this as the molting period duration. If the molting period duration increases with successive stages then we can assume that the variability in development time is increasing. We have attempted to quantify this with the DTV index. This approach is similar to the one used by Peterson (1986) to assess variability in development rates of Calanus marshallae. The DTV index is the inverse of the slope of the cumulative proportion curve for a given stage and provides an estimate of the time (d) that it takes the cohort to complete a molt. If there were no variability in development times, then all values should equal 1.0 since eggs were laid over $24 \mathrm{~h}$. A lengthening of the DTV index relative to the index of earlier stages indicates an increase in the variability of development times.

Growth: Growth rates in terms of $\mathrm{N}$ and $\mathrm{C}$ were determined for egg to N3, N3 to N6, and all copepodite stages in the high food treatments. Because of the spreading of the stage distributions at medium and low food levels and the need to pool a large number of individuals to obtain accurate $\mathrm{CN}$ measurements, especially in younger stages, stage-specific growth rates could not be determined and, instead, were determined for each cohort as a whole over selected time intervals. By separating the measurements where the

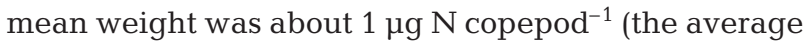
size of a $\mathrm{C} 1$ in the high food treatment), we were able to estimate overall naupliar and copepodite growth rates in these treatments.

Growth rates for individual stages and the grouped stages were assumed exponential and were calculated from the equation:

$$
g=\ln \left(W_{t+1} / W_{t}\right) / T
$$

where $g$ is the exponential growth rate in terms of $\mathrm{N}$ or $\mathrm{C}\left(\mathrm{d}^{-1}\right), W_{t+1}$ and $W_{t}$ are the mean weights ( $\mu \mathrm{g} \mathrm{N}$ or $\mathrm{C}$ ) of the copepods at time $t+1$ and $t$ respectively, and $T$ is the time interval $(d)$.

The weight-specific egg-production-rate (WS-EPR; $\mathrm{d}^{-1}$ ) was estimated from the equation:

$$
\text { WS-EPR }=E / W
$$

where $E$ is the weight of the total egg mass ( $N$ or $C$ ) produced by the female and $W$ is the weight ( $\mathrm{N}$ or $\mathrm{C}$ ) of the female. The WS-EPR is not an exponential rate, since the mass of eggs are shed into the water column and not accumulated in body mass as is growth in younger stages.

General: Mean food concentrations in each tank during each day were calculated by assuming an exponential decline after each food addition using the equation of Omori \& Ikeda (1984):

$$
(C)=\left(C_{t+1}-C_{t}\right) /\left(\ln C_{t+1}-\ln C_{t}\right)
$$

where $(C)$ is the mean concentration, $C_{t}$ is the concentration at time $t$ (after adjustment) and $C_{t+1}$ the concentration at time $t+1$ (prior to adjustment). These mean concentrations, not the target concentrations, were used for determining functional relationships.

All statistical analyses, including ANOVA, post-hoc tests and both linear and non-linear regressions, were performed with PC-SAS Version 6.12 (SAS Institute Inc, Cary, NC). For ANOVA, the individual measurement was the basic unit of data, and since in most cases this resulted in an unbalanced design, the 'general linear models' (GLM) procedure was used. We employed a nested design with variance among tanks as the error term in order to test for both temperature and food level effects. For regressions, the mean tank value was the basic unit of data unless otherwise indicated. Several types of curves were used to describe functional relationships between development, growth, or body size and temperature or food concentration. All curves were fit by the linear least-squares method using DeltaGraph (Version 4.5). DeltaGraph determines the best parameter estimates with an iterative algorithm, the Levenberg-Marquardt method. 


\section{RESULTS}

\section{General findings (Table 1)}

Development time (egg to C5) in Calanus finmarchicus decreased while $\mathrm{N}$ and $\mathrm{C}$ growth rates (N3 to $\mathrm{C} 5$ ) increased with increasing temperature and concentration of food. Carbon growth rates were greater than nitrogen growth rates, as indicated by the ratio of $\mathrm{C}$ growth rate to $\mathrm{N}$ growth rate. The ratios were similar in all high food treatments, with only a slight increase observed with decreasing temperature. However, the ratio did decrease with decreasing food concentration at $8^{\circ} \mathrm{C}$, where $\mathrm{N}$ and $\mathrm{C}$ growth rates were almost equivalent in the lowest food treatment. Both males and females were produced in all experimental tanks, except for Tank L1 at $8^{\circ} \mathrm{C}$. No consistent effect of temperature on sex ratio was observed. About a third of the adults were males in the 4 and $12^{\circ} \mathrm{C}$ tanks, while only half as many were males at $8^{\circ} \mathrm{C}$. The proportion of males was lower in the medium and low food treatments compared to the high food treatment at $8^{\circ} \mathrm{C}$

\section{Size and condition}

\section{Stage effects}

In the high food treatments, there were significant differences between stages in terms of length, $\mathrm{N}$, and C ( $p<0.0001$, ANOVA; Fig. 1). Copepods increased their size in terms of length and $\mathrm{N}$ through to adult female, and in terms of $\mathrm{C}$ through $\mathrm{C} 5$ at all temperatures (Fig. 1). Carbon content decreased significantly between late C5 and adult female at all temperatures, although this is not apparent from Fig. 1 because the size at the midpoint of C5 is shown, not the maximum size.

At $4^{\circ} \mathrm{C}$, the transition from $\mathrm{C} 5$ to adult was prolonged and we were able to monitor the changes in size of these stages for 2 mo at about weekly intervals. This started 4 to $8 \mathrm{~d}$ after $50 \%$ of the populations had reached $\mathrm{C} 5$ and continued until the end of the experiment (Fig. 2). There was no change in length in either stage during this time. There was a significant effect of time on $\mathrm{N}$ and $\mathrm{C}$ for C5 (ANOVA, p < 0.001). Most of this change occurred at the beginning of the observations, when the second sample was significantly higher than the first $(p<0.05$, Student-NewmanKeuls post-hoc test). There were no significant differences among the samples from the second sample onward. Adult females increased significantly over time in $\mathrm{N}(\mathrm{p}<0.01$, ANOVA), but not in $\mathrm{C}$. They were significantly smaller than C5 in terms of $C(p<0.0005$, ANOVA), but became larger in terms of $\mathrm{N}(\mathrm{p}<$ 0.0001, ANOVA) towards the end of the experiment. This increase in female $\mathrm{N}$ content appeared to be caused by growth within the stage rather than by larger C5 molting into females over time. (Although not as closely monitored, these same patterns in body size change between $\mathrm{C} 5$ and adult females were also observed at 8 and $12^{\circ} \mathrm{C}$.)

Table 1. Calanus finmarchicus. Summary of experimental conditions and major findings for each tank. Temperature, tank food level and replicate number $(\mathrm{H}=$ high, $\mathrm{M}=$ medium, $\mathrm{L}=\mathrm{low})$, mean food concentration with coefficient of variation in parentheses (see 'Methods' for estimation of food concentrations), development time from midpoint of egg-laying period to midpoint of C5, mean nitrogen or carbon exponential growth rate from N3 to C5, ratio of carbon growth rate to nitrogen growth rate, and the proportion of adults that were males. Tank L1 at $8^{\circ} \mathrm{C}$ was terminated at Stage C3 and therefore major findings are not reported

\begin{tabular}{|c|c|c|c|c|c|c|}
\hline Tank & $\begin{array}{c}\text { Mean food } \\
\text { conc. } \\
\left(\mu g \mathrm{C}^{-1}\right)\end{array}$ & $\begin{array}{l}\text { Development time } \\
\text { for egg to C5 } \\
\text { (d) }\end{array}$ & $\begin{array}{c}\text { Nitrogen } \\
\text { growth rate, } \\
\text { N3 to C5 } \\
\left(\mathrm{d}^{-1}\right)\end{array}$ & $\begin{array}{c}\text { Carbon } \\
\text { growth rate, } \\
\text { N3 to C5 } \\
\left(\mathrm{d}^{-1}\right)\end{array}$ & $\begin{array}{c}\text { C:N } \\
\text { growth }\end{array}$ & $\begin{array}{c}\text { Proportion } \\
\text { of males }\end{array}$ \\
\hline \multicolumn{7}{|l|}{$12^{\circ} \mathrm{C}$} \\
\hline $\mathrm{H} 1$ & $335(0.26)$ & 22 & 0.25 & 0.29 & 1.15 & 0.27 \\
\hline $\mathrm{H} 2$ & $364(0.25)$ & 23 & 0.25 & 0.28 & 1.13 & 0.32 \\
\hline \multicolumn{7}{|l|}{$8^{\circ} \mathrm{C}$} \\
\hline H1 & $344(0.19)$ & 32 & 0.19 & 0.21 & 1.13 & 0.17 \\
\hline $\mathrm{H} 2$ & $333(0.21)$ & 32 & 0.19 & 0.22 & 1.17 & 0.13 \\
\hline M1 & $39(0.21)$ & 46 & 0.11 & 0.13 & 1.11 & 0.03 \\
\hline M2 & $40(0.34)$ & 46 & 0.12 & 0.13 & 1.10 & 0.05 \\
\hline L1 & $23(0.29)$ & & & & & \\
\hline L2 & $24(0.27)$ & 59 & 0.09 & 0.09 & 1.04 & 0.10 \\
\hline \multicolumn{7}{|l|}{$4^{\circ} \mathrm{C}$} \\
\hline $\mathrm{H} 1$ & $390(0.22)$ & 56 & 0.11 & 0.13 & 1.18 & 0.36 \\
\hline $\mathrm{H} 2$ & $371(0.26)$ & 56 & 0.11 & 0.13 & 1.18 & 0.30 \\
\hline
\end{tabular}



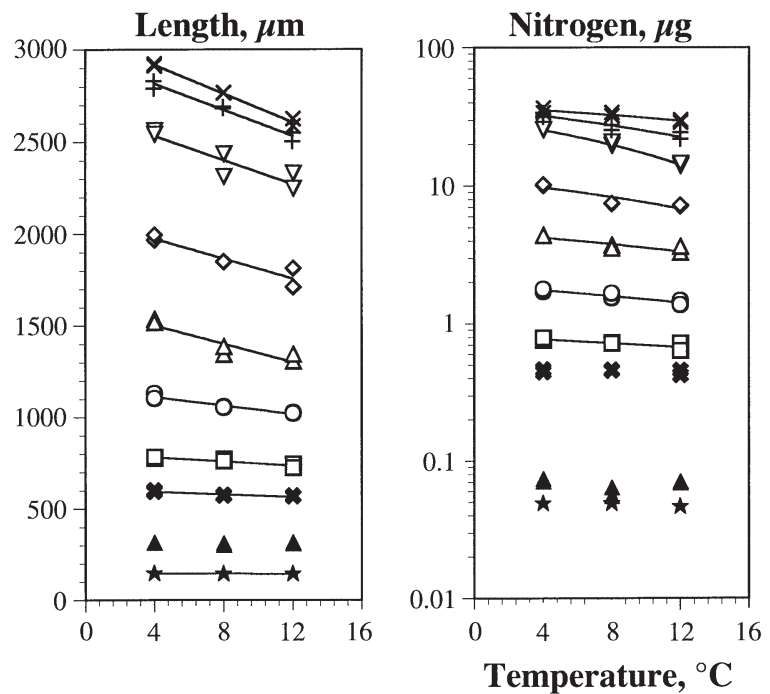

Fig. 1. Calanus finmarchicus. Size versus temperature relationships. Effects of temperature on $L$ (egg diameter, nauplius total length, copepodite prosome length), N, and C. Linear regressions were fit by the least-squares method for each stage. Length regressions were fit to actual measurements while weights $(\mathrm{N}$ and C) were corrected for relative sampling time by exponential interpolation before performing regressions (see 'Methods'). Significant regressions are indicated by lines $(\mathrm{p}<0.05)$. (Equation and parameter estimates are given in Table 2)
There were also significant differences in C:N ratio, nitrogen condition factor (NCF), and carbon condition factor (CCF) among stages in the high food treatments ( $p<0.0001$, ANOVA; Fig. 3). The C:N ratio increased gradually from N3 to $\mathrm{C} 4$, dramatically during $\mathrm{C} 5$, and then declined in the adult stages. The CCF did not change very much during the early copepodite stages, but again there was a large increase during $\mathrm{C} 5$ and a decline in the adult stage. The NCF decreased slightly during early copepodite stages and in later stages showed a similar, although less pronounced, pattern to that found for CCF. The effect of stage of development on $\mathrm{C}: \mathrm{N}$ and $\mathrm{CCF}$ reflected an increase in lipid storage in the older stages, particularly C5 (Fig. 3).

\section{Temperature effects}

Temperature had a negative effect on length, $\mathrm{N}$, and $\mathrm{C}$ (Fig. $1 ; \mathrm{p}<0.0001$, ANOVA). Significant regressions were found for all stages except N3 for length, all copepodite stages for $\mathrm{N}$, and eggs and all copepodite stages for C (Fig. 1, Table 2). In addition, there was a significant overall effect of temperature on C:N ratio (Fig. $3 ; \mathrm{p}<0.0001$, ANOVA). The effects of temperature on the $\mathrm{C}: \mathrm{N}$ ratio were significant for eggs and C2 to C5 ( $p<0.05)$, but not for late C5 and adults. No significant effects of temperature on $\mathrm{N}$ or $\mathrm{C}$ condition factors were found (Fig. 3).

Fig. 2. Calanus finmarchicus. Change in size of $\mathrm{C} 5$ and adult females $(\mathrm{C} 6 \mathrm{~F})$ in $4^{\circ} \mathrm{C}$ tanks over time. Prosome length, $\mathrm{N}$, and $\mathrm{C}$ for $\mathrm{C} 5$ and adult females from each tank at each sampling period are shown. Data are means with standard deviations indicated by error bars
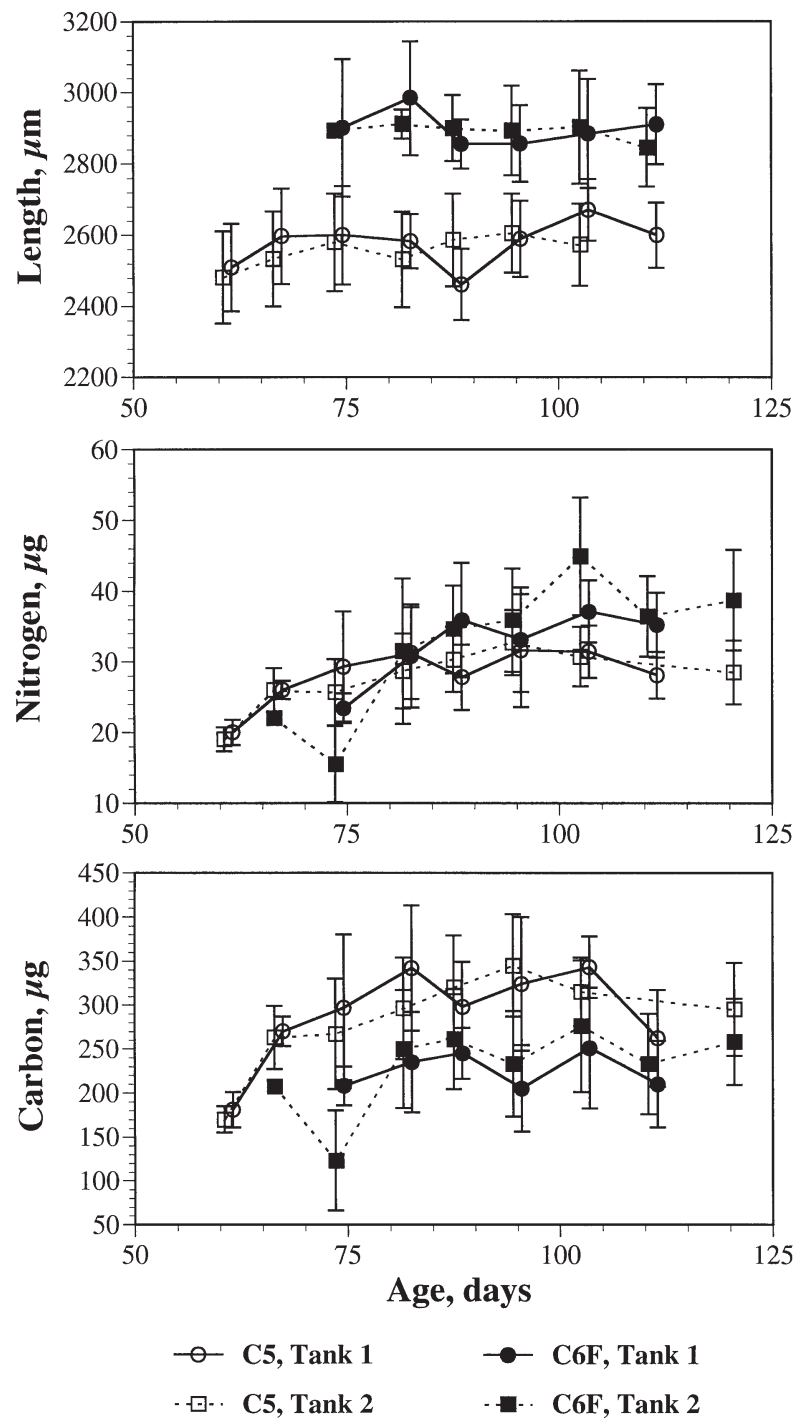


\section{Food concentration effects}

There was a considerable effect of food concentration on length (Fig. 4; p < 0.0001, ANOVA). Length decreased with decreasing food concentration from N6 onward, but the effect was not significant until C1. Significant effects of food concentration on size and condition were observed for Stages C5 and C6F (Fig. 4). Weight ( $\mathrm{N}$ and $\mathrm{C}$ ) and measures of condition (C:N, $\mathrm{NCF}_{\text {, }}$ and $\mathrm{CCF}$ ) of $\mathrm{C} 5$ and $\mathrm{C} 6 \mathrm{~F}$ all significantly declined with decreasing food concentration $(p<0.01$, ANOVA). In the low food concentrations, younger
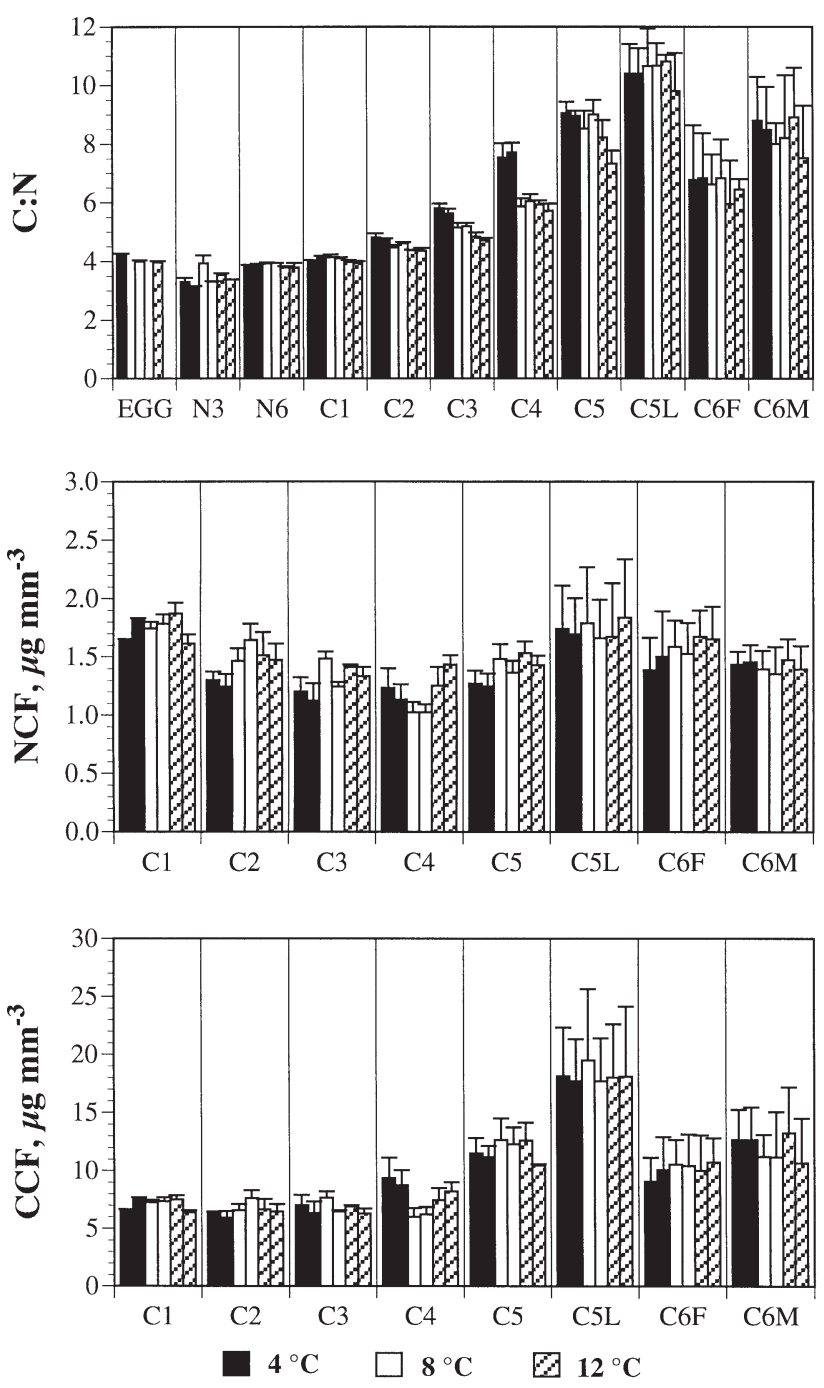

Fig. 3. Calanus finmarchicus. Effects of temperature on condition. C:N ratio, nitrogen condition factors (NCF) and carbon condition factors (CCF) for each stage and replicate temperature treatment are shown. Values for all stages are given for $\mathrm{C}: \mathrm{N}$ ratio, but only copepodite stages for condition factors. For Stage C5, measurements taken near the midpoint (C5) and late in the stage (C5L) are shown. Data are means (actual measurements not corrected for age within stage) with standard deviations indicated by error bars. F: females; M: males
Table 2.Calanus finmarchicus. Effect of temperature on size for several developmental stages. Parameter estimates are given for least-squares linear regressions for length (egg diameter, nauplius total length or copepodite prosome length) and nitrogen and carbon content. Length regressions were fit to actual measurements while nitrogen and carbon weights (N3 through C5) were corrected for relative sampling time before performing regressions (see 'Methods' for explanation). Weights for eggs and adults were not corrected. For eggs, individual measurements were used in the regressions since only 1 set of measurements was made for each temperature treatment (length: $n=150 ; N$ and $C: n=9$ ). For all other stages tank means were used in the regressions for all measurements $(n=6)$. ${ }^{*}$ Significant regressions $(p<0.05)$. Model: size $=m T+b$, where size is the length $(\mu m)$, nitrogen $(\mu g)$ or carbon $(\mu \mathrm{g})$ content of the stage and $T$ is the temperature $\left({ }^{\circ} \mathrm{C}\right)$

\begin{tabular}{|c|c|c|c|}
\hline $\begin{array}{l}\text { Stage, } \\
\text { Statistic }\end{array}$ & Length & Nitrogen & Carbon \\
\hline \multicolumn{4}{|l|}{ Egg } \\
\hline $\mathrm{m}$ & -0.405 & $-2.98 \mathrm{E}-04$ & -0.00255 \\
\hline $\mathrm{b}$ & 147 & 0.0506 & 0.216 \\
\hline $\mathrm{r}^{2}$ & 0.0594 & 0.1845 & 0.5061 \\
\hline $\mathrm{p}$ & $0.0015^{*}$ & 0.1376 & $0.019^{*}$ \\
\hline \multicolumn{4}{|l|}{ N3 } \\
\hline $\mathrm{m}$ & -0.250 & $-2.70 \mathrm{E}-04$ & $9.46 \mathrm{E}-04$ \\
\hline $\mathrm{b}$ & 310 & 0.0693 & 0.226 \\
\hline $\mathrm{r}^{2}$ & 0.0330 & 0.0212 & 0.0615 \\
\hline $\mathrm{p}$ & 0.7306 & 0.7833 & 0.6356 \\
\hline \multicolumn{4}{|l|}{ N6 } \\
\hline $\mathrm{m}$ & -3.75 & -0.00191 & -0.0117 \\
\hline $\mathrm{b}$ & 607 & 0.463 & 1.825 \\
\hline $\mathrm{r}^{2}$ & 0.7864 & 0.1809 & 0.0885 \\
\hline $\mathrm{p}$ & $0.0116^{*}$ & 0.4005 & 0.2899 \\
\hline \multicolumn{4}{|l|}{ C1 } \\
\hline $\mathrm{m}$ & -5.75 & -0.0122 & -0.0593 \\
\hline $\mathrm{b}$ & 803 & 0.818 & 3.39 \\
\hline$r^{2}$ & 0.7678 & 0.6371 & 0.6763 \\
\hline $\mathrm{p}$ & $0.0138^{*}$ & $0.0353^{*}$ & $0.0277^{*}$ \\
\hline \multicolumn{4}{|l|}{ C2 } \\
\hline $\mathrm{m}$ & -11.8 & -0.0413 & -0.276 \\
\hline $\mathrm{b}$ & 1157 & 1.913 & 9.39 \\
\hline$r^{2}$ & 0.9031 & 0.8421 & 0.8903 \\
\hline $\mathrm{p}$ & $0.0023^{*}$ & $0.0063^{*}$ & $0.0030^{*}$ \\
\hline \multicolumn{4}{|l|}{ C3 } \\
\hline $\mathrm{m}$ & -25.3 & -0.113 & -1.09 \\
\hline $\mathrm{b}$ & 1603 & 4.67 & 28.9 \\
\hline $\mathrm{r}^{2}$ & 0.8238 & 0.7567 & 0.8932 \\
\hline $\mathrm{p}$ & $0.0078^{*}$ & $0.0152^{*}$ & $0.0028^{*}$ \\
\hline \multicolumn{4}{|l|}{ C4 } \\
\hline $\mathrm{m}$ & -27.4 & -0.368 & -4.71 \\
\hline $\mathrm{b}$ & 2084 & 11.2 & 94.0 \\
\hline$r^{2}$ & 0.8534 & 0.7635 & 0.8214 \\
\hline $\mathrm{p}$ & $0.0054^{*}$ & $0.0144^{*}$ & $0.0081^{*}$ \\
\hline \multicolumn{4}{|l|}{ C5 } \\
\hline $\mathrm{m}$ & -33.1 & -1.39 & -18.8 \\
\hline $\mathrm{b}$ & 2665 & 30.9 & 332 \\
\hline $\mathrm{r}^{2}$ & 0.7893 & 0.9918 & 0.9882 \\
\hline $\mathrm{p}$ & $0.0133^{*}$ & $<0.0001^{*}$ & $<0.0001^{*}$ \\
\hline \multicolumn{4}{|l|}{$\mathrm{C} 6 \mathrm{~F}$} \\
\hline $\mathrm{m}$ & -39.1 & -0.720 & -6.26 \\
\hline $\mathrm{b}$ & 3073 & 38.2 & 262 \\
\hline $\mathrm{r}^{2}$ & 0.9878 & 0.8023 & 0.7114 \\
\hline $\mathrm{p}$ & $<0.0001^{*}$ & $0.0099^{*}$ & $0.0218^{*}$ \\
\hline \multicolumn{4}{|l|}{ C6M } \\
\hline $\mathrm{m}$ & -35.5 & -1.20 & -11.4 \\
\hline $\mathrm{b}$ & 2957 & 36.9 & 320 \\
\hline $\mathrm{r}^{2}$ & 0.9634 & 0.8645 & 0.6708 \\
\hline $\mathrm{p}$ & $0.0003^{*}$ & $0.0046^{*}$ & $0.0287^{*}$ \\
\hline
\end{tabular}


stages were not measured separately, and thus stagespecific comparisons could not be made; numbers of adult males were too small for valid comparisons.

\section{Development}

Temperature and stage effects

At high food concentrations, there was little spread in the stage distributions over time; the cohorts tended to molt together over very short time intervals (Fig. 5). The development time of all stages decreased with increasing temperature with the time to develop from egg to $\mathrm{C} 5$ decreasing from $56 \mathrm{~d}$ at $4^{\circ} \mathrm{C}$ to 22 and $23 \mathrm{~d}$ at $12^{\circ} \mathrm{C}$ (Table 1). Development times were described well by Belehrádek temperature functions (Fig. 6A, Table 3). These functions allow us to predict development times or stage durations for any stage between 4 and $12^{\circ} \mathrm{C}$ grown under non-limiting food conditions. At $4^{\circ} \mathrm{C}$, stage duration of C5 was prolonged and these data were eliminated from the model fit (Fig. 6A). These longer stage durations of $\mathrm{C} 5$ at $4{ }^{\circ} \mathrm{C}$ appeared to have resulted from the initiation of diapause. A large proportion of the C5 did not appear to be feeding and RNA:DNA ratios of these copepods declined over time to levels approaching those of diapausing copepods from the field (see Wagner et al. 2001).

Stage durations were equiproportional; the relative duration of a given stage (i.e. stage duration/egg duration) was constant over all experimental temperatures with the exception of $\mathrm{C} 5$ at $4^{\circ} \mathrm{C}$ (Fig. 7A). Stage durations, however, were not isochronal; that is, stage durations were not constant over all developmental stages (Fig. 7A). At a given temperature, the non-feeding stages (N1 and N2) were short in duration, the first feeding stage (N3) prolonged, the durations of N4 to N6 were similar to each other, and copepodite stage durations increased with increasing developmental stage.

\section{Food concentration effects}

In contrast to the high food treatments, in the medium and low food treatments there was a considerable spreading in the stage distributions because of increased variability in the development rate of indi-
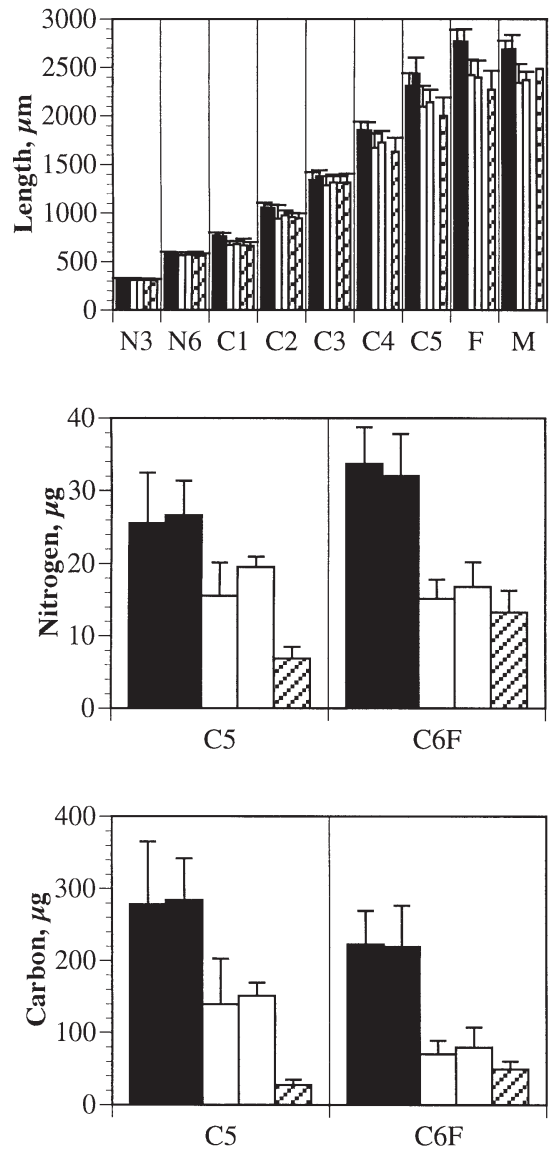
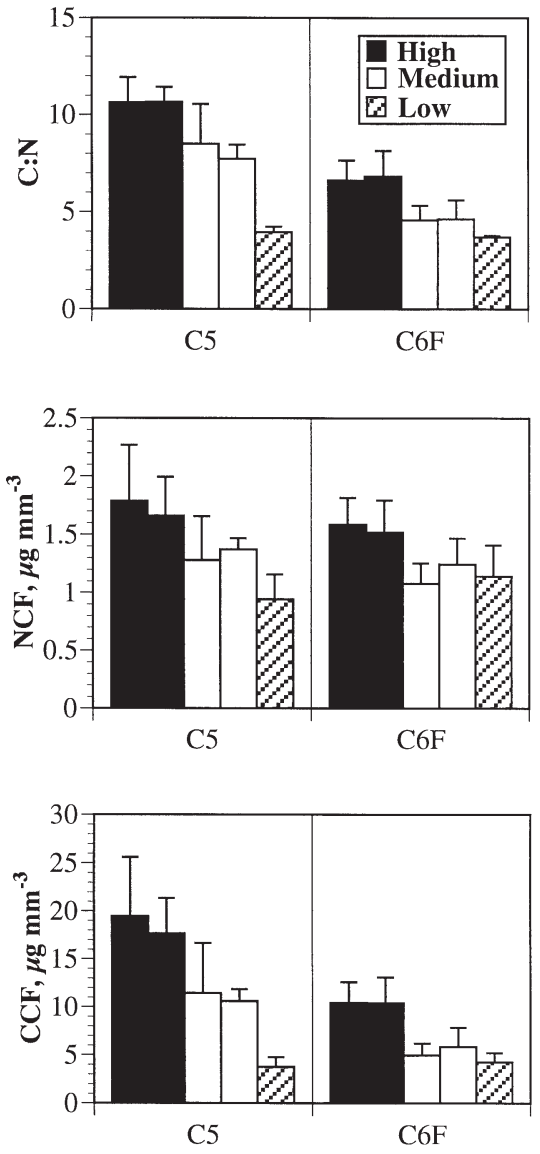

Fig. 4. Calanus finmarchicus. Effects of food concentration on size and condition. Length (nauplius total length, copepodite prosome length), weight ( $\mathrm{N}$ and $\mathrm{C}$ ), and condition (C:N, NCF, and $\mathrm{CCF}$ ) in high, medium, and low food levels at $8^{\circ} \mathrm{C}$. Length measurements for N3, N6, and all copepodite stages including males $(\mathrm{M})$ and females $(\mathrm{F})$ are shown. Weight and condition measurements are only shown for C5 and adult females $(\mathrm{C} 6 \mathrm{~F})$. Because of the spreading in the stage distribution and the need to group copepods $<\mathrm{C} 5$ to obtain a measurement, weight and condition measurements could only be determined for $\mathrm{C} 5$ and adult females in the food-limited treatments. 

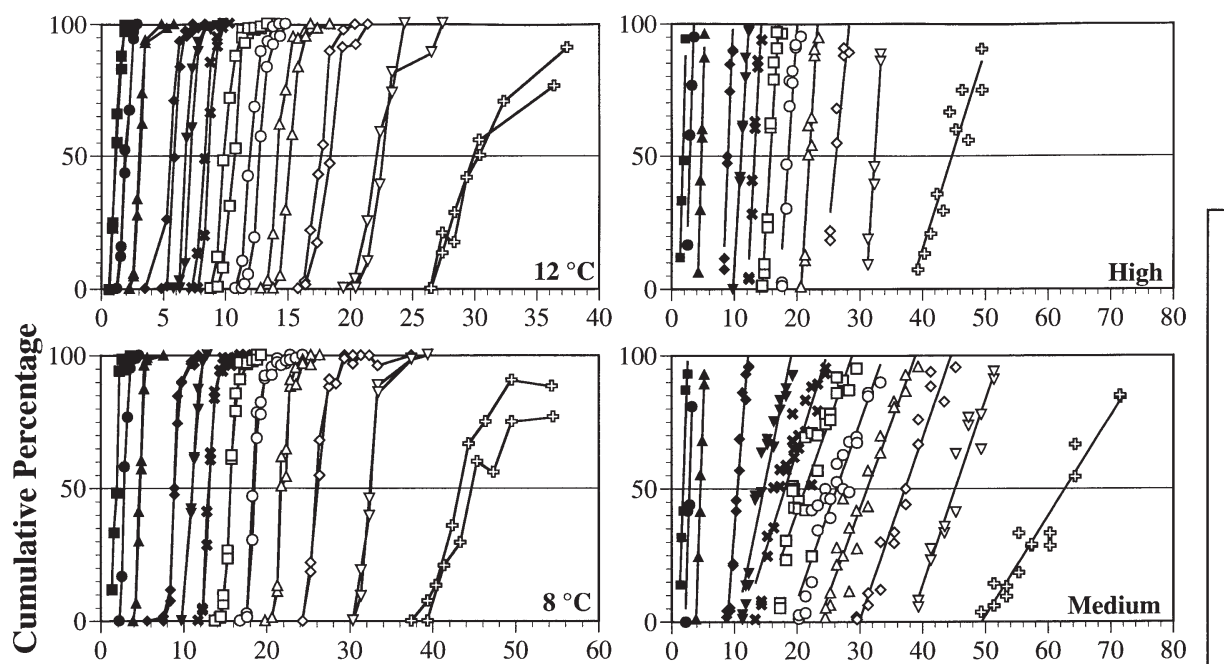

$\bullet \mathrm{N} 1$
$\bullet \mathrm{N} 2$
$\bullet \mathrm{N} 3$
$\bullet \mathrm{N} 4$
$\bullet \mathrm{N} 5$
$* \mathrm{~N} 6$
$\square \mathrm{C} 1$
$\circ \mathrm{C} 2$
$\Delta \mathrm{C} 3$
$\diamond \mathrm{C} 4$
$\nabla \mathrm{C} 5$
$\star \mathrm{C} 6$
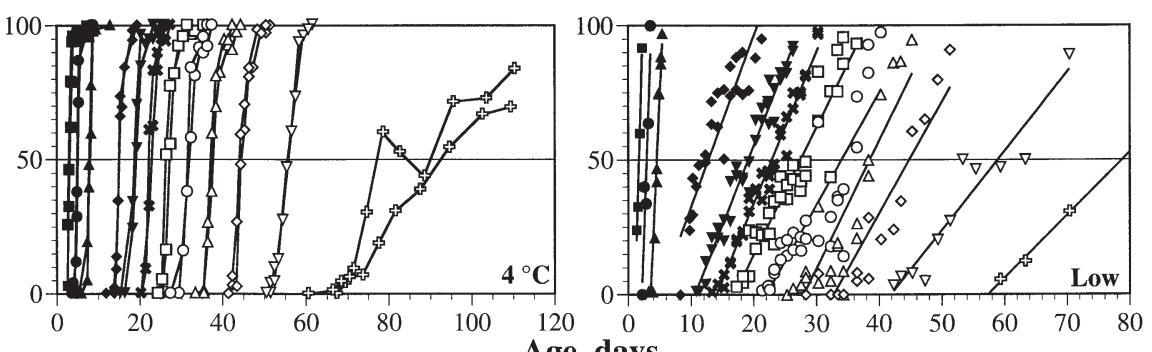

Age, days

Fig. 5. Calanus finmarchicus. Stage progression. Cumulative percentage of copepods or the percentage greater than or equal to a given stage at each sample time for both replicates of each treatment. Left panels: for the temperature treatments, samples from each replicate tank are connected by lines. Right panels: for the food level treatments, regression lines are used to illustrate progression of the cohorts. These lines were not used to calculate development times, as each tank was analyzed separately
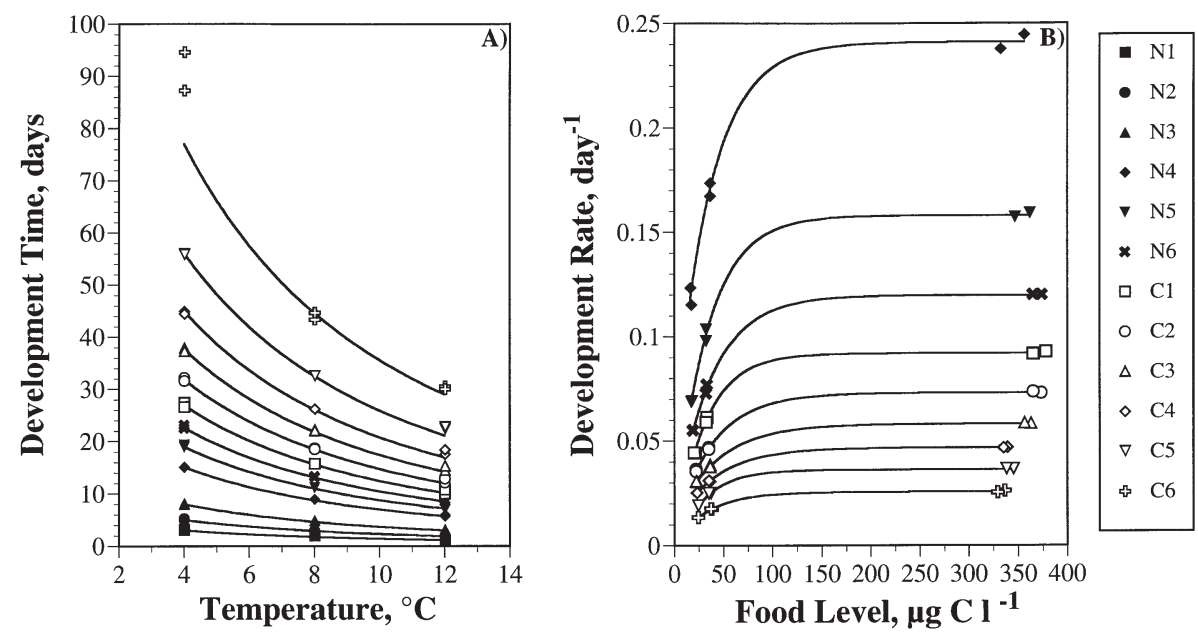

Fig. 6. Calanus finmarchicus. (A) Development time versus temperature. Belehrádek temperature functions were fit to stage development times for the 3 temperature treatments under non-limiting food conditions, including both replicates for each temperature, according to the method of Corkett et al. (1986) (see 'Methods'). The longer development time from C5 to adult in the $4{ }^{\circ} \mathrm{C}$ treatment appeared to be result of the initiation diapause in a significant number of the copepods and was therefore eliminated from the model fit. Parameter estimates are given in Table 3 for each stage. (B) Development rate versus food concentration. In order to illustrate the relationship, Ivlev functions were fit to stage development rates for the 3 food concentrations at $8^{\circ} \mathrm{C}$, including both replicate tanks for each food level. Model: $R=\mathrm{a}\left(1-\mathrm{e}^{[-\mathrm{b}(x-\mathrm{c})]}\right)$, where $R\left(\mathrm{~d}^{-1}\right)$ is the development rate, a is the asymptotic value, $\mathrm{b}$ is the slope or degree of curvature, $x\left(\mu \mathrm{C} \mathrm{Cl}^{-1}\right)$ is the food concentration, and c is the $x$-intercept or threshold concentration. Food concentrations are the mean concentrations over the interval for which development rate was measured 
Table 3. Calanus finmarchicus. Effect of temperature on development time from egg to a given stage. Belehrádek temperature functions were fit to the data as described in the 'Methods'. Model: $D T=$ a $(T+9.11)^{-2.05}$, where $D T$ is development time from midpoint of the egg-laying period to time when $50 \%$ of the copepods have reached a given stage, and $T$ is temperature in ${ }^{\circ} \mathrm{C}$. Parameter estimates for ' $\mathrm{a}$ ' for each stage were fit by least-squares method. Curve fits for each stage are shown in Fig. 6A

\begin{tabular}{|ccc|}
\hline Stage & $\mathrm{a}$ & $\mathrm{r}^{2}$ \\
\hline $\mathrm{N} 1$ & 595 & 0.9913 \\
$\mathrm{~N} 2$ & 983 & 0.9967 \\
$\mathrm{~N} 3$ & 1564 & 0.9983 \\
$\mathrm{~N} 4$ & 2951 & 0.9991 \\
$\mathrm{~N} 5$ & 3710 & 0.9987 \\
$\mathrm{~N} 6$ & 4426 & 0.9987 \\
$\mathrm{C} 1$ & 5267 & 0.9980 \\
$\mathrm{C} 2$ & 6233 & 0.9987 \\
$\mathrm{C} 3$ & 7370 & 0.9987 \\
$\mathrm{C} 4$ & 8798 & 0.9988 \\
$\mathrm{C} 5$ & 10964 & 0.9989 \\
C6 & 15047 & 0.9937 \\
\hline
\end{tabular}

vidual copepods. This resulted in an increased variability and less certainty in the stage duration estimates (Fig. 5). Development rates (the inverse of development time) of all feeding stages decreased with decreasing food concentration (Fig. 6B) and as a result, stage durations of the feeding stages (N3 to $\mathrm{C} 5$ ) in the medium and low food treatments at $8^{\circ} \mathrm{C}$ were on average 1.5 and 2 times longer than the high food treatment, respectively.

Despite the spreading of the stage distributions and prolonged stage durations, the pattern of development

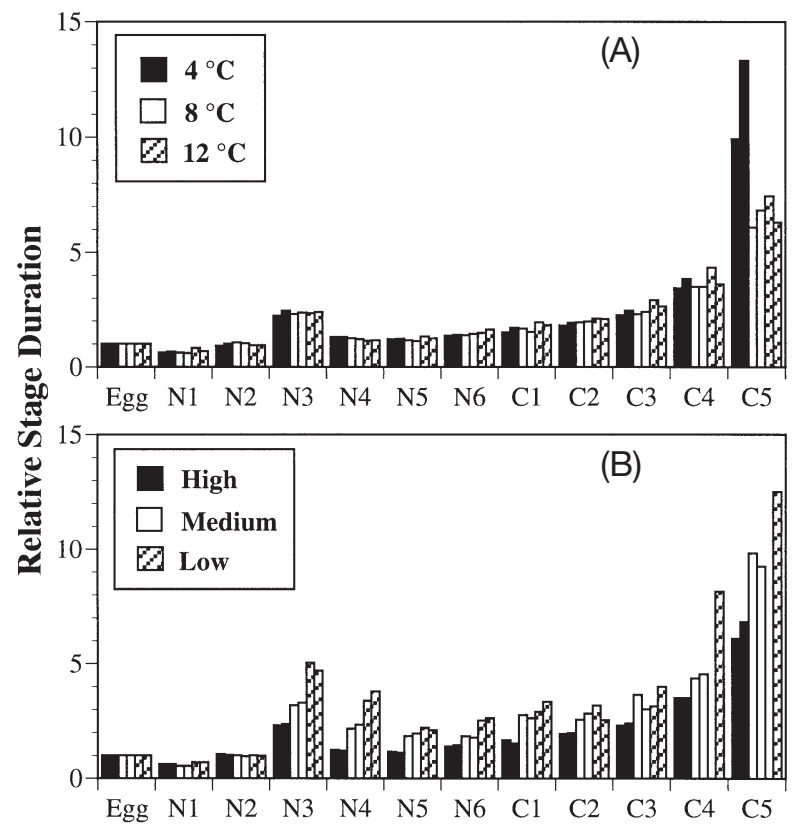

Fig. 7. Calanus finmarchicus. Effects of (A) temperature and (B) food concentration on relative stage durations (stage duration/egg duration) for all stages from both replicate tanks at each temperature or food level

in the medium and low food treatments was remarkably similar to that of the high food treatments (Fig. 7B). The first feeding stage was prolonged and stage durations increased during the copepodite stages. Food limitation appeared to have the same relative effect on copepodite and naupliar stages. Development rates, the inverse of development time, were reduced by about one-third and one-half in the

Table 4.Calanus finmarchicus. Effect of food concentration on development and growth rates at $8^{\circ} \mathrm{C}$. Development rate $\left(\mathrm{d}^{-1}\right)$, $\mathrm{N}$ and $\mathrm{C}$ growth rates $\left(\mathrm{d}^{-1}\right)$, ratio of $\mathrm{C}$ growth to $\mathrm{N}$ growth, and proportion of maximum development and growth rates attained in the food-limited treatments are shown. Development and growth rate comparisons include development from N3 to C1 for nauplii and C1 to C5 for copepodites

\begin{tabular}{|c|c|c|c|c|c|c|c|c|}
\hline \multirow{2}{*}{$\begin{array}{l}\text { Food } \\
\text { level }\end{array}$} & \multirow[t]{2}{*}{ Tank } & \multirow[t]{2}{*}{ Development } & \multirow[t]{2}{*}{ N growth } & \multirow[t]{2}{*}{ C growth } & \multirow[t]{2}{*}{ C:N growth } & \multicolumn{3}{|c|}{ Proportion of maximum } \\
\hline & & & & & & Development & N growth & C growth \\
\hline \multicolumn{9}{|l|}{ Nauplii } \\
\hline \multirow[t]{2}{*}{ High } & 1 & 0.092 & 0.248 & 0.251 & 1.01 & & & \\
\hline & 2 & 0.091 & 0.232 & 0.250 & 1.08 & & & \\
\hline \multirow{2}{*}{ Medium } & 1 & 0.061 & 0.142 & 0.155 & 1.09 & 0.66 & 0.59 & 0.62 \\
\hline & 2 & 0.059 & 0.154 & 0.164 & 1.06 & 0.64 & 0.64 & 0.65 \\
\hline \multirow[t]{2}{*}{ Low } & 1 & 0.044 & 0.096 & 0.102 & 1.06 & 0.48 & 0.40 & 0.41 \\
\hline & 2 & 0.044 & 0.109 & 0.117 & 1.07 & 0.48 & 0.46 & 0.47 \\
\hline \multicolumn{9}{|c|}{ Copepodites } \\
\hline \multirow[t]{2}{*}{ High } & 1 & 0.060 & 0.156 & 0.192 & 1.24 & & & \\
\hline & 2 & 0.060 & 0.159 & 0.198 & 1.25 & & & \\
\hline \multirow[t]{2}{*}{ Medium } & 1 & 0.041 & 0.082 & 0.090 & 1.09 & 0.69 & 0.52 & 0.46 \\
\hline & 2 & 0.042 & 0.083 & 0.094 & 1.14 & 0.71 & 0.53 & 0.48 \\
\hline Low & 2 & 0.032 & 0.057 & 0.056 & 0.97 & 0.54 & 0.37 & 0.29 \\
\hline
\end{tabular}


medium and low food treatments, respectively, for both naupliar and copepodite stages (Table 4). In addition, estimates of the critical food concentrations required to achieve $90 \%$ of the maximum development rate from Ivlev functions fit to the data were about $70 \mu \mathrm{g} \mathrm{C}^{-1}$ for both nauplii and copepodites (Fig. 8).

\section{Development time variability (DTV)}

The variability in development times was only slightly affected by temperature, but was greatly affected by food concentration, as shown by the DTV index (Fig. 9). Under conditions of surplus food, the DTV index was lengthened gradually from egg hatching up to the molt into C5 (Fig. 9). It took only a little more than $1 \mathrm{~d}$ for the eggs to hatch once hatching began, while molting from $\mathrm{C} 4$ to $\mathrm{C} 5$ lasted 3 to 7 times longer. The index was lengthened slightly for $4^{\circ} \mathrm{C}$ relative to the warmer temperatures. The DTV index for molting into the adult stage was much greater than for the earlier stages, and this was especially lengthened at $4^{\circ} \mathrm{C}$. However, the severe lengthening in the $4^{\circ} \mathrm{C}$ tanks appeared to be caused by a significant portion of the population attempting to go into diapause, as we have discussed earlier. The effect of food concentration

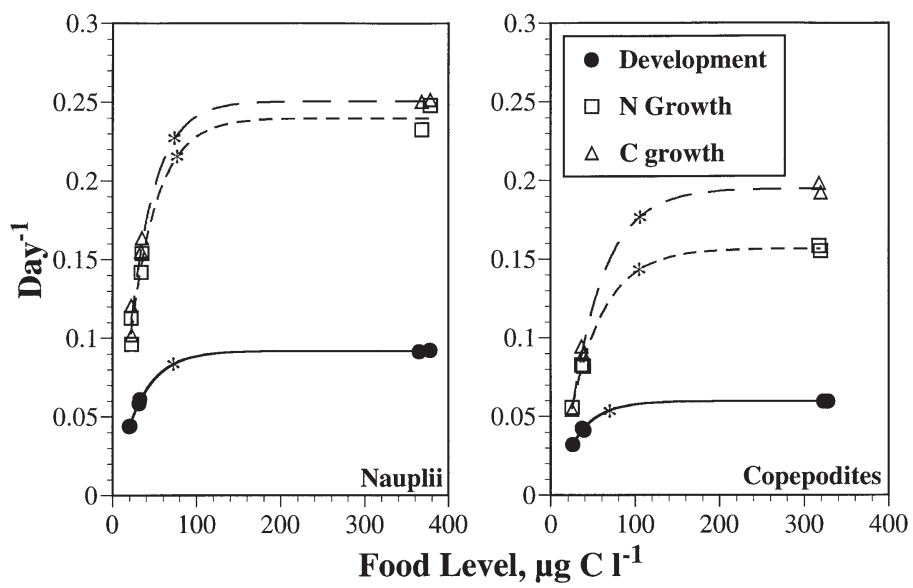

Fig. 8. Calanus finmarchicus. Effect of food concentration on development and growth rate at $8{ }^{\circ} \mathrm{C}$. Development and growth rates of nauplii and copepodite stages were measured at 3 different food levels. Values are means for each tank; for nauplii, $\mathrm{n}=6$, for copepodites, $\mathrm{n}=5$. See 'Methods' for explanation of how stages were grouped for the analysis. Ivlev functions with an $x$-intercept were fit to the development and growth rate data as for development rates in Fig. 6B. Food concentrations are mean concentrations over the interval for which the rate was measured. Critical concentrations $(*)$, the food concentrations at which $90 \%$ of the maximum rate was achieved, for development, $\mathrm{N}$ growth, and $\mathrm{C}$ growth respectively were 70, 76, and $71 \mu \mathrm{g} \mathrm{Cl}^{-1}$ for nauplii, and 69, 103, and $105 \mu \mathrm{g} \mathrm{C} \mathrm{l}^{-1}$ for copepodites

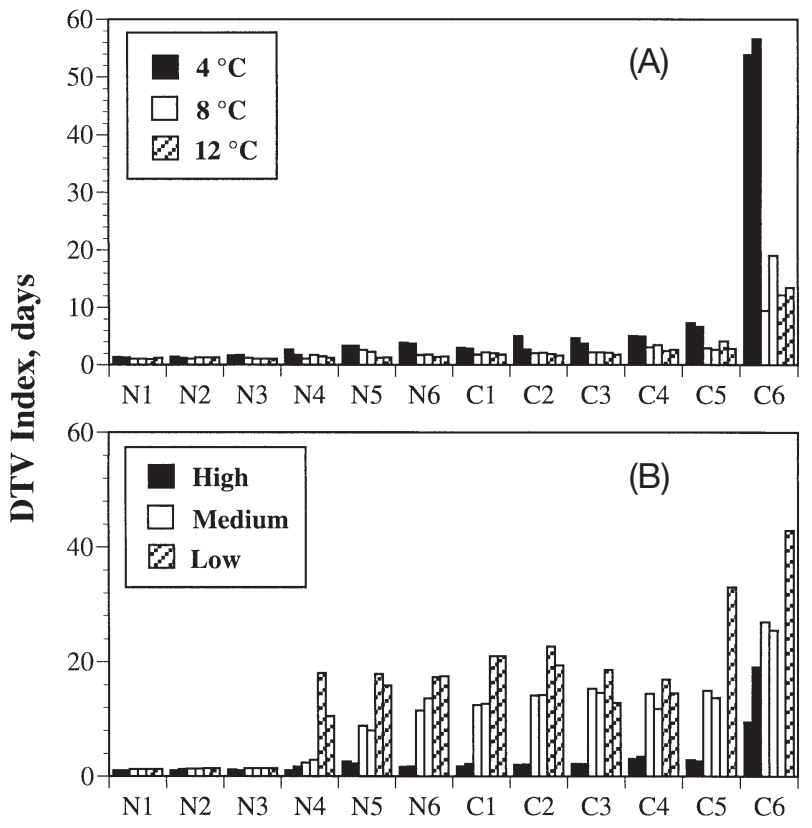

Fig. 9. Calanus finmarchicus. Variability in development times. Development-time-variability (DTV) index for molting into a given stage is shown for both replicates of each (A) temperature or (B) food level treatment

on the index was much greater than temperature (Fig. 9). In the medium food levels, there was a gradual lengthening relative to the high food levels, beginning with the molt from the first feeding stage and continuing through to the molt into the final naupliar stage where it remained constant until the final molt. In the lower food levels, there was an immediate lengthening of the index after the first feeding stage; it then remained relatively constant until the final 2 molts, when it again increased.

\section{Growth}

Temperature and stage effects

The mean $\mathrm{N}$ - and $\mathrm{C}$-specific growth rates between egg and $\mathrm{C} 5$ increased with increasing temperature, more than doubling between 4 and $12^{\circ} \mathrm{C}$ (Table 1). However, while growth rates were accelerated at warmer temperatures, maximum body weights were smaller (Fig. 10A,B). Growth rates were not exponential over the entire life cycle, decreasing substantially in older stages, which suggested a more sigmoidal shape to the size versus age curve. This decrease in growth rates was almost 2 -fold between $\mathrm{C} 1$ and $\mathrm{C} 4$ at all temperatures (Fig. 11).

Growth rates showed the same pattern with respect to stage at all temperatures (Fig. 11). Growth rates 
were high between Naupliar Stages N3 to N6, decreased at the transition from N6 to $\mathrm{C} 1$, increased again from $\mathrm{C} 1$ to $\mathrm{C} 2$, and declined with older copepodite developmental stage. Negative carbon growth rates were observed between egg and N3, which included growth of the 2 non-feeding stages (N1, N2). Nitrogen growth rates also were low between egg and N3, but there did not appear to be much, if any, loss in nitrogen during the non-feeding developmental period. (N3 carbon and nitrogen measurements for the growth calculations were made just after the copepods had molted to this stage and had begun to feed; this resulted in a minimum of growth during the first feeding stage included in the egg to N3 growth rates, although in most cases some growth probably did occur.)

Predictive relationships for $\mathrm{N}$ and $\mathrm{C}$ growth rate versus temperature were determined for each copepodite stage and for groups of naupliar stages (feeding or non-feeding) (Fig. 12, Table 5). Regressions were significant for all growth intervals ( $p<0.05$ ), except for egg to N3 and C5 to C6 carbon growth.
Carbon growth relative to nitrogen growth increased with increasing stage of development from 1.0-1.1 for N3-N6 to 1.4-1.7 within C5 (Fig. 13). This was an indication of increased lipid deposition in later stages. However, no consistent pattern with respect to temperature was observed.

\section{Food concentration effects}

Mean growth rates of all stages decreased by more than a factor of 2 between the high and low food levels at $8^{\circ} \mathrm{C}$ (Table 1). Food limitation had a greater affect on $\mathrm{C}$ growth than $\mathrm{N}$ growth, as shown by the decline in the ratio of $\mathrm{C}$ growth rate to $\mathrm{N}$ growth rate with increased degree of food limitation (Table 1).

The same pattern in body size changes over time found in the high food treatments was also observed in the medium and low food treatments (Fig. 10C,D). As in the high food treatments, growth rates appeared to follow a sigmoidal relationship in the food-limited treatments. Growth was higher during the early stages and decreased during the copepodite stages as the copepods approached their maximum body weight. However, because of an overall reduction in growth rates in the lower food treatments, maximum body weights were smaller. The effect of food concentration on growth rate appeared to be more severe in older stages, especially at the lowest food level.

Nauplii and copepodites responded differently to food limitation, with a smaller reduction in growth rate by nauplii than by copepodites for a given food level (Table 4). In addition, the food concentration at which growth became limited (the critical concentration where growth was $90 \%$ of the maximum rate) was greater for copepodites than nauplii, about 100 and $75 \mu \mathrm{g} \mathrm{C} \mathrm{l}^{-1}$ respectively (Fig. 8).

There were also differences between nauplii and copepodites in the degree to which $\mathrm{C}$ and $\mathrm{N}$ growth was reduced. Nauplii showed a similar reduction of both $\mathrm{C}$ and $\mathrm{N}$ growth rates while copepodites showed a greater reduction of $\mathrm{C}$ growth than of $\mathrm{N}$ growth (Table 4). As a result, the $\mathrm{C}: \mathrm{N}$ growth ratio was unaffected by food level for naupliar

Fig. 10. Calanus finmarchicus. Effects of temperature and food on growth. (A,B Mean $\mathrm{N}$ and $\mathrm{C}$ content of copepods grown at high food concentration at 4, 8, and $12^{\circ} \mathrm{C}$ as a function of time. (C,D) Mean $\mathrm{N}$ and $\mathrm{C}$ content of copepods grown at high, medium, and low food concentrations at $8^{\circ} \mathrm{C}$ as a function of time. Chapman-Richards growth equations were fit using both replicates for each treatment to illustrate the sigmoidal relationship between weight and age (Vidal 1980a) Model: $W=W_{\max }\left(1+\mathrm{Be}^{-k t}\right)^{-m}$, where $W$ is the weight ( $\mu \mathrm{g} \mathrm{N}$ or $\mathrm{C}$ ) at time $t$ and $W_{\max }$ is the asymptotic weight. The fits only included Stages N3 to late C5 


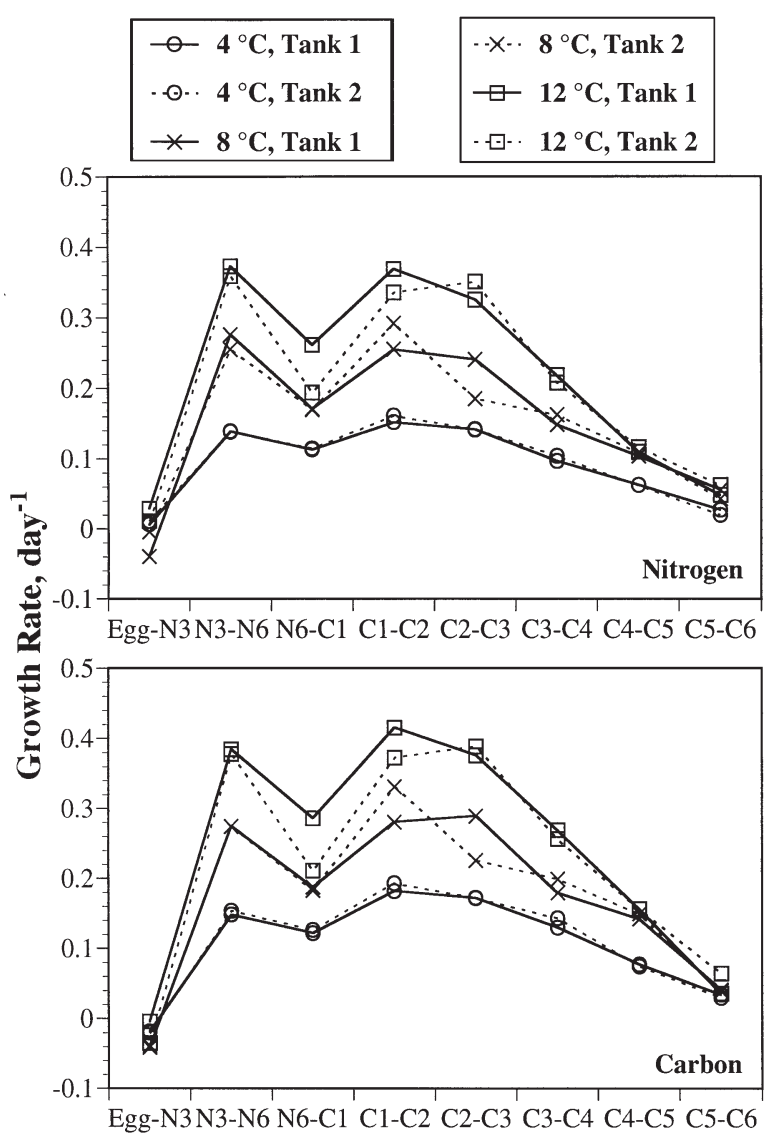

Growth Interval

Fig. 11. Calanus finmarchicus. Stage-specific patterns in growth rate. Mean $\mathrm{N}$ and $\mathrm{C}$ growth rates $\left(\mathrm{d}^{-1}\right)$ for different growth intervals for copepods grown under non-limiting food concentrations. Both replicates for each temperature treatment $\left(4,8\right.$, and $\left.12^{\circ} \mathrm{C}\right)$ are shown stages, while for copepodites it decreased with decreasing food level, an indication that $\mathrm{C}$ growth was more severely affected than $\mathrm{N}$ growth (Table 4).

\section{Egg production}

Clutch size, egg production rates (EPR), and weightspecific egg production rates (WS-EPR) were higher at 4 than $8^{\circ} \mathrm{C}$ (Table 6 ). The spawning frequency ranged between 0.55 and 0.85 .

\section{DISCUSSION}

This study is the most comprehensive laboratory investigation of Calanus finmarchicus growth and development rates to date. It builds on the work of Corkett et al. (1986), who first showed that development in C. finmarchicus was equiproportional. It was designed to allow investigators in the US GLOBEC Northwest Atlantic Georges Bank Study to assess growth and development rates of $C$. finmarchicus in the field and to supply muchneeded stage duration information for models. Results from this study have already been used for assessing food limitation of $C$. finmarchicus in the field (Campbell et al. 2001) and for modeling C. finmarchicus populationdynamics (Lynch et al. 1998, Miller et al. 1998).

\section{Culturing conditions and sex ratios}

The copepods reared in the experiment, even at $12^{\circ} \mathrm{C}$, were larger and generally in better condition
Fig. 12. Calanus finmarchicus. Predictive relationships for $\mathrm{N}$ and $\mathrm{C}$ growth rates as a function of temperature for copepods reared at non-limiting food concentrations. Logarithmic regressions were fit to nitrogen- and carbonspecific growth rates for the different growth intervals using the linear least-squares method. Lines indicate significant regressions $(\mathrm{p}<0.05)$. Dashed lines indicate relationships for naupliar stages and solid lines relationships for copepodites. (See Table 5 for equation and parameter estimates)
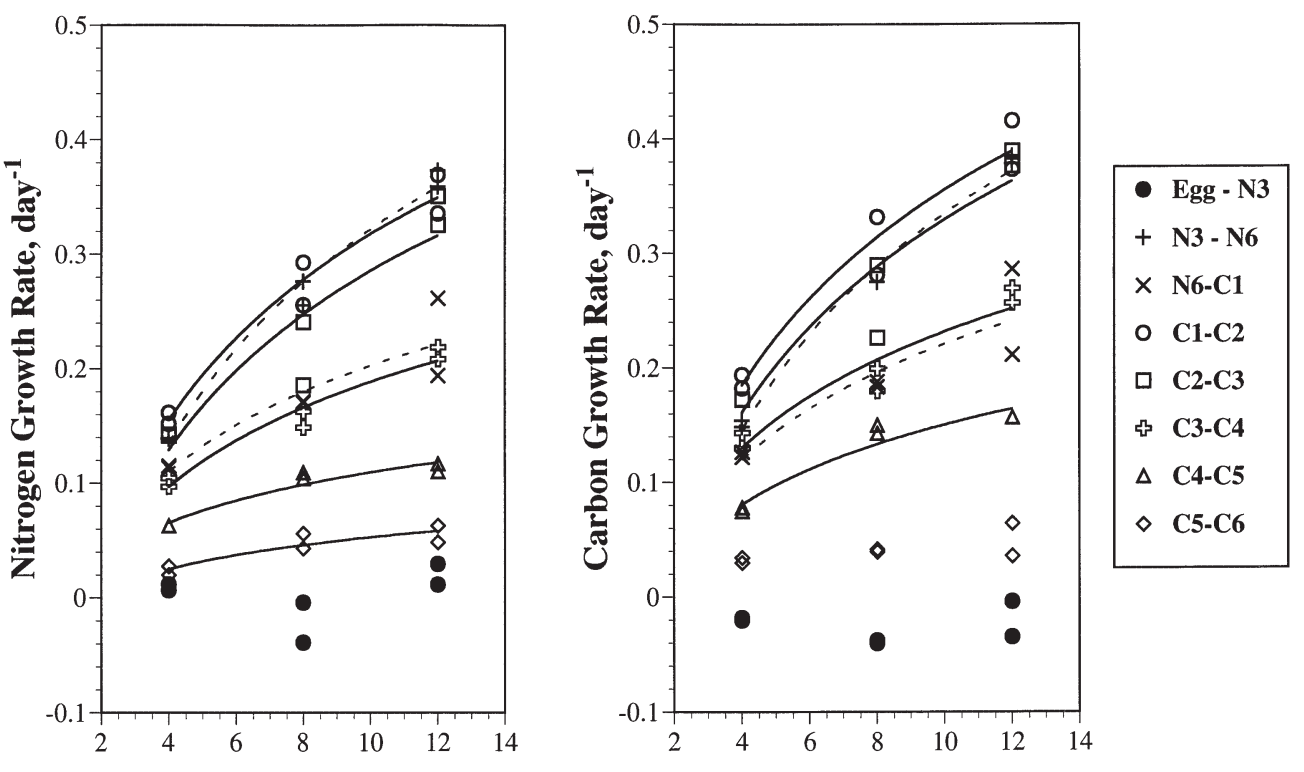

Temperature, ${ }^{\circ} \mathrm{C}$ 


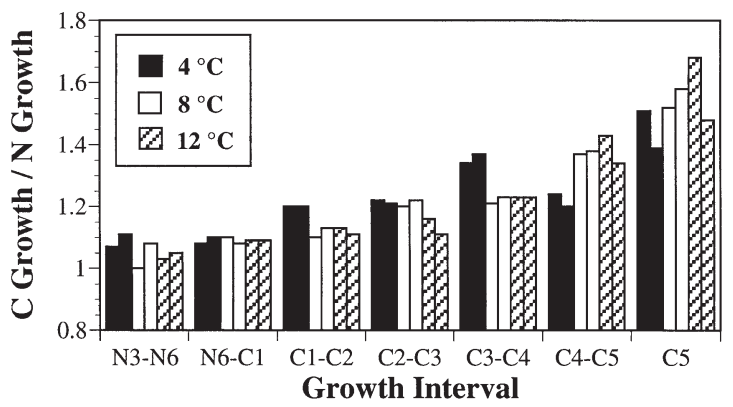

Fig. 13. Calanus finmarchicus. Effect of temperature and developmental stage on the ratio of carbon growth rate to nitrogen growth rate under non-limiting food conditions. Data are mean ratios for different growth intervals for copepods grown under non-limiting food concentrations. Also shown are ratios for growth within $\mathrm{C} 5$. For $\mathrm{C} 5$ growth estimates at 8 and $12{ }^{\circ} \mathrm{C}$, adults that were present in the final sample were not included in the calculations. No C5s had molted in samples used in the $4^{\circ} \mathrm{C}$ calculations. Both replicates for each temperature treatment $\left(4,8\right.$, and $\left.12^{\circ} \mathrm{C}\right)$ are shown

than those collected from the field (Table 7). The C:N ratios and CCFs were higher for the laboratory-reared copepods while the NCFs were more similar. This suggests that the rearing conditions in the laboratory were at least as good if not better than field conditions.

Food quality and quantity, as well as container size appears to affect the sex ratio in Calanus spp. with greater proportions of males in better quality food conditions and in larger containers. In the high food treatments, the proportions of males were greater than in most previously published Calanus spp. rearing studies. In contrast, in the food-limited treatments the proportions of males were reduced. Low proportions of males were also found in our preliminary rearing experiments, in which food conditions were similar to those in the present study but where copepods were reared in crowded conditions in small containers. In previous studies, low proportions of males have been found for Calanus spp. or related species reared in small containers (<5 l) (Hirche 1980, Peterson 1986,
Table 5. Calanus finmarchicus. Effect of temperature on nitrogen or carbon growth rate for different growth intervals for copepods reared at high food concentration. Parameter estimates are given for least-squares logarithmic regressions $(\mathrm{n}=6) .{ }^{*}$ Significant regressions $(\mathrm{p}<0.05)$. Model: growth $\left(\mathrm{d}^{-1}\right)=\mathrm{b}+\mathrm{m} \times \ln T\left({ }^{\circ} \mathrm{C}\right)$

\begin{tabular}{|c|c|c|}
\hline $\begin{array}{c}\text { Interval, } \\
\text { Statistic }\end{array}$ & Nitrogen & Carbon \\
\hline \multicolumn{3}{|l|}{ Egg-N3 } \\
\hline $\mathrm{m}$ & 0.00433 & -0.00313 \\
\hline $\mathrm{b}$ & -0.00628 & -0.0199 \\
\hline $\mathrm{r}^{2}$ & 0.0087 & 0.0119 \\
\hline $\mathrm{p}$ & 0.8609 & 0.8369 \\
\hline \multicolumn{3}{|l|}{ N3-N6 } \\
\hline $\mathrm{m}$ & 0.204 & 0.206 \\
\hline b & -0.148 & -0.140 \\
\hline $\mathrm{r}^{2}$ & 0.9838 & 0.9846 \\
\hline $\mathrm{p}$ & $<0.0001^{*}$ & $<0.0001^{*}$ \\
\hline \multicolumn{3}{|l|}{ N6-C1 } \\
\hline $\mathrm{m}$ & 0.101 & 0.110 \\
\hline $\mathrm{b}$ & -0.0298 & -0.0331 \\
\hline $\mathrm{r}^{2}$ & 0.7869 & 0.7805 \\
\hline $\mathrm{p}$ & $0.0116^{*}$ & $0.0123^{*}$ \\
\hline \multicolumn{3}{|l|}{$\mathrm{C} 1-\mathrm{C} 2$} \\
\hline $\mathrm{m}$ & 0.177 & 0.186 \\
\hline $\mathrm{b}$ & -0.0910 & -0.0729 \\
\hline $\mathrm{r}^{2}$ & 0.9580 & 0.9328 \\
\hline $\mathrm{p}$ & $0.0004^{*}$ & $0.0011^{*}$ \\
\hline \multicolumn{3}{|l|}{$\mathrm{C} 2-\mathrm{C} 3$} \\
\hline $\mathrm{m}$ & 0.170 & 0.184 \\
\hline $\mathrm{b}$ & -0.107 & -0.0940 \\
\hline $\mathrm{r}^{2}$ & 0.8349 & 0.8662 \\
\hline $\mathrm{p}$ & $0.0069^{*}$ & $0.0045^{*}$ \\
\hline \multicolumn{3}{|l|}{ C3-C4 } \\
\hline $\mathrm{m}$ & 0.1000 & 0.111 \\
\hline $\mathrm{b}$ & -0.0420 & -0.0235 \\
\hline $\mathrm{r}^{2}$ & 0.9492 & 0.902 \\
\hline $\mathrm{p}$ & $0.0006^{*}$ & $0.0024^{*}$ \\
\hline \multicolumn{3}{|l|}{ C4-C5 } \\
\hline $\mathrm{m}$ & 0.0479 & 0.0761 \\
\hline $\mathrm{b}$ & -0.00125 & -0.0250 \\
\hline $\mathrm{r}^{2}$ & 0.9099 & 0.9158 \\
\hline $\mathrm{p}$ & $0.0020^{*}$ & $0.0017^{*}$ \\
\hline \multicolumn{3}{|l|}{ C5-C6 } \\
\hline $\mathrm{m}$ & 0.0300 & 0.0159 \\
\hline $\mathrm{b}$ & -0.0167 & 0.00931 \\
\hline $\mathrm{r}^{2}$ & 0.7644 & 0.2736 \\
\hline $\mathrm{p}$ & $0.0143^{*}$ & 0.1647 \\
\hline
\end{tabular}

Table 6. Calanus finmarchicus. Egg production rates of females at 4 and $8^{\circ} \mathrm{C}$ in high food treatments. Approximate age of females in days after $50 \%$ of the population had matured (time after maturity); mean $\mathrm{N}$ and $\mathrm{C}$ female body weight; proportion of females that produced clutches (spawning frequency); mean clutch size (no. of eggs), where n refers to number of clutches produced and may include more than 1 from a given female; mean egg production rate (EPR: eggs female $\mathrm{d}^{-1}$ ) for all females in incubation whether or not they produced clutches; weight-specific egg production rate (WS-EPR), proportion of female body $\mathrm{N}$ or $\mathrm{C}\left(\mathrm{d}^{-1}\right)$

\begin{tabular}{|c|c|c|c|c|c|c|c|c|}
\hline \multirow{2}{*}{ Tank } & \multirow{2}{*}{$\begin{array}{l}\text { Time after } \\
\text { maturity (d) }\end{array}$} & \multicolumn{2}{|c|}{ Female weight } & \multirow{2}{*}{$\begin{array}{l}\text { Spawning } \\
\text { frequency }\end{array}$} & \multirow{2}{*}{$\begin{array}{l}\text { Clutch size } \\
\qquad\left(\mathrm{SD}_{\mathrm{i}} \mathrm{n}\right)\end{array}$} & \multirow{2}{*}{$\begin{array}{c}\text { EPR } \\
(\mathrm{SD} ; \mathrm{n})\end{array}$} & \multicolumn{2}{|c|}{ WS-EPR } \\
\hline & & $\mu g \mathrm{~N}$ & $\mu g \mathrm{C}$ & & & & $\mathrm{N}\left(\mathrm{d}^{-1}\right)$ & $C\left(d^{-1}\right)$ \\
\hline \multicolumn{9}{|l|}{$4^{\circ} \mathrm{C}$} \\
\hline 1 & 28 & 35 & 216 & 0.65 & $74(37 ; 14)$ & $52(56 ; 20)$ & 0.07 & 0.05 \\
\hline 2 & 15 & 36 & 233 & 0.85 & $73(34 ; 18)$ & $66(45 ; 20)$ & 0.09 & 0.06 \\
\hline \multicolumn{9}{|l|}{$8^{\circ} \mathrm{C}$} \\
\hline 1 & 10 & 36 & 237 & 0.55 & $53(17 ; 14)$ & $37(40 ; 20)$ & 0.05 & 0.03 \\
\hline 2 & 9 & 33 & 232 & 0.80 & $52(21 ; 20)$ & $52(48 ; 20)$ & 0.08 & 0.04 \\
\hline
\end{tabular}


Table 7. Calanus finmarchicus. Comparison between size and condition of laboratory-reared copepods with field-collected specimens from Georges Bank and the Gulf of Maine collected between November 1994 and November 1995. Data for laboratory study are means (not corrected for age within stage) for all copepods grown under non-limiting food concentrations for a given temperature-about 2200 copepods. Data for field-collected copepods are means for more than 5000 copepods collected on 8 cruises. Mean values from each cruise were weighted equally to account for differences in the number of copepods collected. Temperature range in the field was the same as that in the experiment (about 4 to $12^{\circ} \mathrm{C}$ ). $\mathrm{F}$ : females; M: males; NCF, CCF: nitrogen and carbon condition factors respectively

\begin{tabular}{|c|c|c|c|c|}
\hline \multirow[t]{2}{*}{ Stage } & \multicolumn{3}{|c|}{ Lab raised } & \multirow{2}{*}{$\begin{array}{c}\text { Field } \\
\text { collected }\end{array}$} \\
\hline & $4^{\circ} \mathrm{C}$ & $8^{\circ} \mathrm{C}$ & $12^{\circ} \mathrm{C}$ & \\
\hline \multicolumn{5}{|c|}{ Length ( $\mu \mathrm{m})$} \\
\hline C1 & 777 & 765 & 731 & 663 \\
\hline $\mathrm{C} 2$ & 1115 & 1053 & 1021 & 970 \\
\hline $\mathrm{C} 3$ & 1522 & 1360 & 1320 & 1327 \\
\hline C4 & 1982 & 1850 & 1763 & 1745 \\
\hline C5 & 2549 & 2370 & 2284 & 2228 \\
\hline $\mathrm{C} 6 \mathrm{~F}$ & 2916 & 2764 & 2603 & 2564 \\
\hline C6M & 2809 & 2685 & 2525 & 2391 \\
\hline \multicolumn{5}{|c|}{ Nitrogen $(\mu g)$} \\
\hline C1 & 0.76 & 0.72 & 0.66 & 0.46 \\
\hline $\mathrm{C} 2$ & 1.69 & 1.61 & 1.42 & 1.12 \\
\hline $\mathrm{C} 3$ & 4.17 & 3.63 & 3.54 & 2.76 \\
\hline $\mathrm{C} 4$ & 9.93 & 7.46 & 7.57 & 6.59 \\
\hline C5 & 30.0 & 26.5 & 26.0 & 16.6 \\
\hline C6F & 36.5 & 33.0 & 29.5 & 27.0 \\
\hline C6M & 33.0 & 26.0 & 23.0 & 20.8 \\
\hline \multicolumn{5}{|c|}{ Carbon $(\mu g)$} \\
\hline C1 & 3.12 & 2.95 & 2.60 & 1.43 \\
\hline $\mathrm{C} 2$ & 7.98 & 7.24 & 6.15 & 4.32 \\
\hline C3 & 24.1 & 19.1 & 17.3 & 11.6 \\
\hline $\mathrm{C} 4$ & 77.2 & 47.5 & 44.7 & 39.5 \\
\hline C5 & 311 & 281 & 265 & 136 \\
\hline C6F & 233 & 221 & 183 & 143 \\
\hline C6M & 284 & 212 & 193 & 133 \\
\hline \multicolumn{5}{|l|}{$C: N$} \\
\hline C1 & 4.09 & 4.13 & 3.96 & 3.12 \\
\hline $\mathrm{C} 2$ & 4.78 & 4.55 & 4.38 & 3.82 \\
\hline C3 & 5.72 & 5.17 & 4.79 & 4.16 \\
\hline $\mathrm{C} 4$ & 7.62 & 5.96 & 5.83 & 6.06 \\
\hline C5 & 10.42 & 10.65 & 10.31 & 8.04 \\
\hline C6F & 6.80 & 6.73 & 6.20 & 5.33 \\
\hline C6M & 8.64 & 8.10 & 8.21 & 6.35 \\
\hline \multicolumn{5}{|l|}{ NCF } \\
\hline C1 & 1.72 & 1.76 & 1.74 & 1.57 \\
\hline $\mathrm{C} 2$ & 1.27 & 1.55 & 1.49 & 1.23 \\
\hline $\mathrm{C} 3$ & 1.16 & 1.36 & 1.37 & 1.17 \\
\hline $\mathrm{C} 4$ & 1.18 & 1.02 & 1.34 & 1.22 \\
\hline C5 & 1.76 & 1.72 & 1.75 & 1.48 \\
\hline C6F & 1.44 & 1.55 & 1.66 & 1.58 \\
\hline C6M & 1.44 & 1.37 & 1.43 & 1.52 \\
\hline \multicolumn{5}{|l|}{ CCF } \\
\hline C1 & 7.05 & 7.27 & 6.89 & 4.90 \\
\hline $\mathrm{C} 2$ & 6.09 & 7.07 & 6.53 & 4.80 \\
\hline C3 & 6.64 & 7.03 & 6.57 & 4.89 \\
\hline $\mathrm{C} 4$ & 9.02 & 6.10 & 7.81 & 7.40 \\
\hline C5 & 18.38 & 18.56 & 18.04 & 12.04 \\
\hline C6F & 9.54 & 10.45 & 10.33 & 8.38 \\
\hline C6M & 12.62 & 11.16 & 11.94 & 9.68 \\
\hline
\end{tabular}

Uye 1988, Peterson \& Painting 1990), and in larger containers (19 l) with only single food types or mixed diatom cultures (e.g. Mullin \& Brooks 1967, 1970b). Higher proportions of males have been obtained by using larger containers and rearing the copepods on mixed diets or better quality food (e.g. Paffenhöfer 1970, Landry 1983, Marcus \& Alatalo 1989).

We were unable to obtain accurate stage-specific estimates of mortality because the variability in our abundance estimates was much higher than the mortality in the tanks. Mortality in the 4 and $8^{\circ} \mathrm{C}$ tanks appeared to be low, and there did not appear to be any effect of food concentration on mortality at $8^{\circ} \mathrm{C}$. In the $12^{\circ} \mathrm{C}$ tanks, mortality was noticeably higher during the copepodite stages. At this temperature, algal growth on the walls and bottom of the tanks occurred at much higher rates, which required more frequent water changes and tank cleaning to control. It was not clear whether the higher mortality in the $12^{\circ} \mathrm{C}$ tanks was indicative of an upper temperature tolerance for Calanus finmarchicus or was simply due to culturing conditions. The latter explanation is more likely, since $C$. finmarchicus has been reared at $19^{\circ} \mathrm{C}$ by Marcus \& Alatalo (1989).

\section{Stage effects}

\section{Size and condition}

Length, $\mathrm{C}$ and $\mathrm{N}$ all increased with increasing stage until C5. Adult females continued to increase in length and $\mathrm{N}$, but showed a considerable decrease in $\mathrm{C}$. In our laboratory study, the loss in carbon appeared to take place during the transition from C5 to adult or shortly thereafter. The lack of any further decrease in adult size over time suggests that the initial decrease was not the direct result of egg release, but instead was associated with changes during the molt to adult female. This may include development of the gonadal system and the production of embryos. Field-collected copepods showed similar patterns of body size with stage, although the laboratory-reared copepods were all slightly larger, even at the warmest temperature (Table 7). Field-collected C5 showed a very large range in $\mathrm{C}$, and although the overall mean was less than that for adult females, the largest C5 were always much larger (Campbell \& Durbin unpubl.), suggesting that they also lose $\mathrm{C}$ on transition to the adult female. High mortality rates in the field may obscure this decreasing $\mathrm{C}$ between $\mathrm{C} 5$ and adult female.

There were changing patterns in structural weight and lipid storage during development, which resulted in significant differences in $\mathrm{C}: \mathrm{N}$ ratio and condition measurements between stages. 'Structural weight' is the total weight of the copepod minus lipid or storage 
products (McLaren 1986). Here we define structural weight as $\mathrm{N}$ weight. Changing proportions of storage are reflected in changing $\mathrm{C}: \mathrm{N}$ ratios. The increasing $\mathrm{C}$ weight relative to $\mathrm{N}$ weight during development, which indicates increased lipid storage, was reflected in a gradual increase in the C:N ratio, with highest ratios occurring at $\mathrm{C} 5$. The CCF was relatively constant during early copepodite stages, and similarly showed the greatest increase during $\mathrm{C} 4$ and $\mathrm{C} 5$. In contrast, the NCF decreased during the copepodite stages through $\mathrm{C} 4$, and although it was higher in $\mathrm{C} 5$ and adult stages, these changes were small compared to changes in CCF. These findings suggest that over the course of development the structural mass ( $\mathrm{N}$ content) per unit volume is relatively constant, but the mass of stored lipid (reflected in increased C) per unit volume increases dramatically in later stages.

\section{Development}

At high food concentrations and over the range of temperatures tested, we found that development rates were not isochronal (Miller et al. 1977), that is, all stage durations were not of equal length. Isochronal development was proposed for members of the copepod genus Acartia by Miller et al. (1977) after analyzing several data sets. Subsequently, most development rate studies on members of the genus Acartia have found that development is isochronal or near isochronal with the exception of the first 2 stages, N1 being much shorter and N2, the first feeding stage, much longer (Landry 1975, Miller et al. 1977, Sekiguchi et al. 1980, Uye 1980, Klein Breteler et al. 1982, Berggreen et al. 1988, Klein Breteler \& Schogt 1994).

However, in an exhaustive review of patterns in copepod post-embryonic durations, only the genus Acartia was found to exhibit isochronal development (Hart 1990). Landry (1983) examined 7 different species of marine copepods from 6 separate genera and found that isochronal development was most closely approached in Acartia spp., but was not a general characteristic applicable to other copepod genera. His findings suggested that even in Acartia spp. isochronal development was not strictly followed, because of the shorter N1 and longer N2 and C5 stage duration, and the more rapid maturation of males compared with females. He advanced several generalizations that could be considered characteristic patterns of development based on his observations. The pre-feeding naupliar stages were short, the first feeding stage (either N2 or N3 depending on the species) had an extended duration, the female C5 stage was prolonged, and males matured faster than females.
The present findings were consistent with Landry's (1983) first 2 generalizations. For the naupliar stages, the first 2 non-feeding stages (N1, N2) were of short duration, the first feeding stage (N3) was prolonged, and the remaining stages (N4 to N6) were of similar and intermediate duration. However, for the copepodites, stage durations increased with increasing stage of development. This pattern was observed in all 3 temperature treatments. Thompson (1982) found a very similar pattern of development in laboratory studies with Calanus species (C. finmarchicus, C. helgolandicus, or a mixture of both). In contrast to these studies, Corkett et al. (1986) found that the stage durations of Stages C1 to C4 of C. finmarchicus were about the same, while $\mathrm{C} 5$ was prolonged (they did not study naupliar durations). However, their overall development times to adult female were similar to our observations. Our total development time was the same as theirs at $8^{\circ} \mathrm{C}$, about $3 \%$ slower at $4{ }^{\circ} \mathrm{C}$, and $5 \%$ faster at $12^{\circ} \mathrm{C}$. The differences in copepodite stage durations between the 2 studies has important implications in terms of growth patterns, and will be discussed below. We believe that our observations of increasing stage durations with increasing copepodite stage are more realistic. Corkett et al. (1986) followed the development of only a few individuals through the copepodite stages. Adults were reared at only 1 temperature $\left(10.5^{\circ} \mathrm{C}\right)$, while younger copepodite stages were reared at several. As a result, there was much less precision in their stage duration estimates compared to those in our study, and a poor fit of their data with their proposed development time-temperature curves (see their Fig. 2). Field molting rate studies with $C$. finmarchicus on Georges Bank conducted as part of the US GLOBEC Northwest Atlantic Georges Bank Study (Campbell \& Durbin unpubl. data) provide further evidence that stage durations increase with increasing developmental stage.

Most copepods appear to show a similar developmental pattern in the naupliar stages, but the increasing stage durations in the copepodite stages that we observed appears to be common only in copepods that store large amounts of lipid. For Calanus spp., short pre-feeding stages and long first feeding naupliar stages have been found for C. pacificus (Fernández 1979, Landry 1983), C. sinicus (Uye 1988), C. australis (Peterson \& Painting 1990), and C. marshallae (Peterson 1986), and increasing stage durations in copepodite stages have been shown for C. pacificus (Vidal 1980b, Landry 1983), C. sinicus (Uye 1988), C. australis (Peterson \& Painting 1990) and C. marshallae (Peterson 1986). Other lipid-storing copepods show these same patterns, e.g. Rhincalanus nasutus (Landry 1983) and Calanoides carinatus (Peterson \& Painting 1990). Mixed results have been found for copepods that store 
lipids to a lesser degree, e.g. for Pseudocalanus spp., in which isochronal or near-isochronal development has sometimes been observed (Klein Breteler et al. 1982, 1990, 1995), whereas at other times the pattern has been more similar to that found in Calanus spp. (Vidal 1980b, Landry 1983, Koski et al. 1998). In contrast, species of copepods that do not have large lipid reserves do not commonly show increasing stage durations in the copepodite stages, but rather have similar stage durations, with the possible exception of a longer C5 stage, e.g. Acartia clausi/hudsonica (Landry 1975, 1983, Sekiguchi et al. 1980, Uye 1980, Klein Breteler et al. 1982, Klein Breteler \& Schogt 1994), A. tonsa (Miller et al. 1977, Landry 1983, Berggreen et al. 1988), Centropages hamatus ( Klein Breteler et al. 1982), and Temora longicornis (Klein Breteler et al. 1982, 1990).

\section{Growth}

Compared with development rate, there have been few studies that have measured growth rate in copepods, fewer still that have measured stage-specific growth rates, and of those, many did not measure growth directly but only estimated growth from development times and weight measurements made on separate groups of copepods. Therefore, patterns in growth rate for different stages of copepods are not well known. In the high-food treatments the patterns in $\mathrm{N}$ and $\mathrm{C}$ growth rates were the same at all temperatures. Growth rates were negative or near zero in the non-feeding stages (egg to N3), high in naupliar stages N3 to N6, low during the transition from N6 to $\mathrm{C} 1$, and decreased with increasing stage of development in the copepodite stages. In the pre-feeding naupliar stages, the loss in $\mathrm{C}$ was much greater than the loss in $\mathrm{N}$, indicating that $\mathrm{N}$ was conserved while $\mathrm{C}$-stores were used for energy for metabolism and morphological changes. The negative growth rates found for pre-feeding stages is not surprising although, as far as we know, it has not been demonstrated before. A decrease in growth rate during the transition from the nauplii and copepodites to the copepodite form has also been observed by Klein Breteler et al. (1982) for Acartia clausi, Temora longicornis, Centropages hamatus, and Pseudocalanus sp., and by Fernández (1979) for Calanus pacificus. It is likely that growth rates were reduced because more energy was required for the morphological changes that took place during this transition. Growth rates in the early copepodites ( $\mathrm{C} 1$ and $\mathrm{C} 2$ ) were similar to the feeding naupliar stages, but decreased during the later stages (C3 to $\mathrm{C} 6$ ). Decreasing growth rates during later copepodite stages has also been found for C. pacificus (Mullin \& Brooks 1970a, Vidal 1980a),
C. sinicus (Uye 1988) and Rhincalanus nasutus (Mullin \& Brooks 1970a). Peterson (1986) found that for $C$. marshallae growth was exponential through $\mathrm{C} 5$, and only declined during the final molt. However, in Peterson's study, growth was not measured directly, but was estimated from development times and weight measurements on different groups of copepods and therefore is not as reliable.

In our experiment, we have underestimated growth rates for $\mathrm{C} 5$ to some extent since a significant portion of the copepods had molted to C6. These had undergone de-growth in terms of $\mathrm{C}$, and much slower growth in terms of $\mathrm{N}$ for an unknown period of time. In the $4^{\circ} \mathrm{C}$ treatment, where we were able to measure growth rates in C5 prior to any copepods molting to the adult stage, they were about twice as high as those between C5 and C6. Adults did not appear to grow very much, and ingested food was used for egg production and metabolism. The slight but significant increase in the female $\mathrm{N}$ content $\left(0.01 \mathrm{~d}^{-1}\right)$ was small relative to $\mathrm{N}$ used for egg production (0.07 to $0.09 \mathrm{~d}^{-1}$ ).

\section{Temperature effects}

\section{Size and condition}

We found that length and weight (as measured by $\mathrm{N}$ and C) were inversely related to temperature. The inverse relationship between temperature and length in copepods has been previously described both in the field (e.g. Deevey 1960, Durbin et al. 1992) and in the laboratory (e.g. Uye 1988, Escribano et al. 1997). Generally, the effect of temperature on length is not observed until the late copepodite stages; however, in our study, there was a significant effect on egg diameter and on the length of all stages except N3. We also found a significant negative effect of temperature on weight for all copepodite stages, similar to that found by Mullin \& Brooks (1970a) and Vidal (1980a). This negative relation has not always been observed, however (e.g. Mullin \& Brooks 1970b, Escribano et al. 1997), perhaps because of culturing conditions not being well controlled or measurements being made on preserved samples (e.g. Escribano et al. 1997).

Temperature had a slight effect on the C:N ratio but not on NCF or CCF. Overall, the C:N ratio did show a slight inverse relationship with temperature, but the effect was not apparent in the later stages. The lack of a relationship between temperature and condition factors (NCF and CCF) indicates that although the copepods were larger in terms of weight and length at colder temperatures, the relative proportions or mass per unit volume remained constant when food was not limiting. 


\section{Development and growth}

While development at a given temperature at high food concentrations was not isochronal, it was equiproportional (e.g. Corkett \& McLaren 1970); the duration of each stage occupied the same proportionate amount of time at all temperatures. Equiproportional development has been found previously for Calanus finmarchicus (Corkett et al. 1986) as well as for other species of copepods including Calanus spp. (Thompson 1982), C. pacificus (Vidal 1980b for C3 to C6), C. sinicus (Uye 1988), Calanoides carinatus (Peterson \& Painting 1990), and Acartia clausi (Sekiguchi et al. 1980). Equiproportional development appears to be a general rule in copepod development and, even within a genera, relative stage durations are strikingly similar (intergeneric equiproportionality) (Hart 1990).

It has been hypothesized that the inverse relationship between temperature and body size in copepods is a result of smaller temperature coefficients for growth rate than for development rate (Miller et al. 1977). This is supported by our observations, whereby we found that at low temperatures development was much slower than at higher temperatures, while growth did not decrease by the same proportionate amount. For overall development and growth to C5 between 4 and $12^{\circ} \mathrm{C}$, the $Q_{10}$ values for development, $\mathrm{N}$ growth, and $\mathrm{C}$ growth were 3.4, 2.8, and 2.6 respectively. This differential effect of temperature occurred primarily in the copepodite stages where the effect of temperature on development was greater than on growth $\left(Q_{10}=3.4,2.4,2.4\right.$, for development, $\mathrm{N}$ growth, and $\mathrm{C}$ growth respectively). In contrast, for naupliar stages, the effect of temperature on development rate and growth rate was similar $\left(Q_{10}=3.4,3.2\right.$ and 3.2 for development, $\mathrm{N}$ and $\mathrm{C}$ growth respectively). Vidal (1980a) also found that the effect of temperature on growth decreased with increasing stage in copepodite stages of Calanus pacificus.

\section{Egg production}

Calanus finmarchicus egg production rates (EPR and WS-EPR) were higher at $4^{\circ} \mathrm{C}$ than at $8^{\circ} \mathrm{C}$. This apparent inverse relationship with temperature appears to be in contrast with the results of other researchers (Runge 1985, Runge \& Plourde 1996, Hirche et al. 1997). It may have been the result of the females in the $8^{\circ} \mathrm{C}$ tanks being younger and not having reached their full reproductive potential. Despite this unexplained finding, the egg production rates were high, an indication that experimental conditions in the tanks were not only very good for growth and development but for reproduction as well. Clutch sizes at 4 and $8^{\circ} \mathrm{C}$ were as high, or higher, than previously reported maximum values (Runge 1985, Hirche et al. 1997), while the EPR and WS-EPR at $4{ }^{\circ} \mathrm{C}$ were higher than the maximum temperature-specific rates reported by Runge (1985) and Runge \& Plourde (1996). At $8^{\circ} \mathrm{C}$ the EPR was higher, but the WS-EPR was lower, than their maximum reported values. The EPR and WS-EPR cannot be compared directly with the data of Hirche et al. (1997), because they selected only those females that were reproducing at high rates for their experiments. At $4^{\circ} \mathrm{C}$ the spawning frequency was near expected rates predicted from the spawning interval-temperature curve of Hirche et al. (1997), while at $8^{\circ} \mathrm{C}$ the frequency was lower than predicted. The lower than expected spawning frequency at $8^{\circ} \mathrm{C}$ could have been caused by either longer inter-clutch intervals, a high proportion of females that had not been fertilized, or a high proportion of females that were reproductively immature. Since we only measured egg production once over a $24 \mathrm{~h}$ interval, we cannot distinguish between these alternatives.

\section{Food concentration effects}

Food limitation affected the copepod populations in the tanks in several different ways: it resulted in decreased size and condition, increased development times, increased variability in stage durations, and lower growth rates.

Size and condition

Both size and condition of the copepods were positively related to food concentration. Condition factors have been used to assess the condition and degree of food limitation of Acartia spp. populations in Narragansett Bay, Rhode Island (Durbin \& Durbin 1978, Durbin et al. 1983, 1992). More recently, Campbell et al. (2001) used condition measurements to assess food limitation of Calanus finmarchicus populations from Georges Bank and found that they were in agreement with direct measurements of growth, development, and egg production. Because condition factors were affected by food level but, as noted earlier, were not affected by temperature, they can be useful tools for assessing food limitation in the field.

\section{Development and growth}

The effects of food concentration on development and growth rates were difficult to assess because of the spreading of the stage distributions in the food-limited 
treatments as well as the additional confounding effects of differences in growth and development rates between stages. In order to smooth out the confounding stage effects, we had to group the stages into naupliar and copepodite stages for the analysis. We analyzed the data in 2 different ways, with both methods leading to identical conclusions. In the first, we simply determined what proportion of the maximum development or growth rates was achieved in the food-limited treatments (Table 4). In the second method, we determined critical concentrations, or the concentration of food required to achieve $90 \%$ of the maximum rate from Ivlev curves fit to the data (Fig. 8). Although only 3 food concentrations were used, we have confidence in the results. Each concentration was replicated and there was very good agreement between each replicate in both development and growth rates at the different food concentrations. The initial slopes were determined from 4 (nauplii) or 3 (copepodites) measurements, providing us with a good estimate of these relationships. While the high food concentration was much greater than the food-limited concentrations, this only sets the asymptotic value of the curve. As long as the highest concentrations are above food-limiting conditions, the shape of the curve will not be affected by the actual value of the concentrations used.

From our study, several general patterns have emerged on the effects of food concentration on development and growth of Calanus finmarchicus. For nauplii, differences in the relations between food concentration and both development and $\mathrm{C}$ and $\mathrm{N}$ growth were small. For copepodite development, the critical concentration was about the same as that observed for nauplii. However, for copepodite $\mathrm{C}$ and $\mathrm{N}$ growth, the critical concentration was considerably greater than for development and, as a result, considerably greater than for growth of nauplii. A similar pattern where growth and development at different food concentrations were more tightly coupled in naupliar stages than in copepodite stages has been observed for Pseudocalanus elongatus (Paffenhöfer \& Harris 1976) and Temora longicornis (Harris \& Paffenhöfer 1976). A greater effect of food limitation on copepodite growth than on development has also been demonstrated for C. pacificus (Vidal 1980a,b), P. elongatus (Paffenhöfer \& Harris 1976) and T. longicornis (Harris \& Paffenhöfer 1976). When critical concentrations for growth and development of $C$. helgolandicus nauplii were determined at a large number of concentrations providing a high degree of resolution, a higher critical concentration for growth than for development was found (Green et al. 1991). It is likely that in other experiments (including ours) the resolution was insufficient to detect the rather small differences in nauplii. These observations indicate that development and growth rates are more tightly coupled for nauplii than for copepodites and that copepodites can maintain maximum development rates at food concentrations that are limiting to growth.

When food was limiting, C growth rates were reduced much more than $\mathrm{N}$ growth rates. The ratio of $\mathrm{C}$ to $\mathrm{N}$ growth for N3 to $\mathrm{C} 5$ in the lowest food concentrations were reduced to the levels of the growth rate ratios observed for nauplii in the high food treatment. This reflects a strong effect of food limitation on lipid storage, particularly in the later copepodite stages. For C5 at the lowest food level, there was little visual evidence of substantial lipid storage and the C:N ratios were reduced to about 4, values similar to those observed in the naupliar stages. A similar greater limitation of $\mathrm{C}$ growth rates than of $\mathrm{N}$ has been observed on Georges Bank (Campbell \& Durbin unpubl. data). These results are not surprising, as it would be expected that copepods would meet structural growth requirements first before allocating $\mathrm{C}$ for storage.

Our results suggest little or no change in the critical food concentration for development with increasing developmental stage. This contrasts with an apparent increasing critical concentration with developmental stage observed by Vidal $(1980 a, b)$. In this study, Calanus pacificus were reared at high food until $\mathrm{C} 1$ and then placed in a number of different food concentrations and growth and development were followed through time. While developmental rates were measured at many more concentrations than in our study, development rates were measured with rather low precision (from no more than 10 samples for all 4 stages, and with development times estimated from some curves fitted by eye to only 1 or 2 data points). However, we feel that the major reason for the differing results is a significant carry-over effect in Vidal's $(1980 a, b)$ experiments. C. pacificus nauplii were reared to $\mathrm{C} 1$ at high food concentrations on a mixed diet at $8^{\circ} \mathrm{C}$ and then placed in the experimental vessels at 3 temperatures and differing food concentrations. Because of the decoupling of development and growth, $\mathrm{C} 2$ in good condition will initially continue to develop at high rates at what would normally be limiting food concentrations. These would then become progressively more food-limited through later stages, resulting in an increasing critical concentration with increasing stage of development. However, despite these differences, the critical concentrations for development and growth of copepodite stages were remarkably similar in both this and Vidal's (1980a,b) study. From Vidal's (1980a,b) data we estimate that the average critical concentrations for development and growth of C. pacificus copepodite stages were about 65 and $100 \mu \mathrm{g} \mathrm{Cl}^{-1}$ respectively, whereas for $C$. finmarchicus copepodites in our study we found about 70 and $100 \mu \mathrm{g} \mathrm{Cl}^{-1}$ respectively. 
The considerable spreading of the stage distributions in the food-limited treatments revealed by the DTV index resulted from an increased variability in stage durations amongst individuals within the cohort. This spreading was a good indicator of less-thanoptimal food conditions and a reflection of the stochastic nature of the feeding process (Beyer \& Laurence 1980). The differential development rate expressed under limiting conditions may have a genetic component. Carlotti \& Nival (1991) also found that under conditions that limit growth, differential development for individually reared Temora stylifera was strongly expressed, and suggested that it might be related to the degree of heterozygosity in the population. They suggested that growth and development rates of individuals that are more strongly heterozygotic would be less dependent on environmental conditions than those that are relatively more homozygotic because the costs of various metabolic processes would be less.

\section{Is growth exponential in copepods?}

It has been widely assumed that growth in copepods is exponential and thus weight-specific growth rates for all stages are the same (e.g. Sekiguchi et al. 1980, Kiørboe \& Johansen 1986, Peterson 1986, Berggreen et al. 1988, Uye 1988, McLaren \& Leonard 1995, Poulet et al. 1995). However, in our study, growth in both $C$ and $\mathrm{N}$ from egg to adult for Calanus finmarchicus at all temperature and food conditions was not exponential, but followed a sigmoidal relationship. Vidal (1980a) also found that growth rate decreased with increasing size in the copepodite stages of C. pacificus, and found a sigmoidal relationship with growth and body size over the range of temperatures tested. Other studies with $C$. pacificus have shown that growth was not exponential but decreased with increasing size (Mullin \& Brooks 1970a) and that growth rates of naupliar stages were not constant (Fernández 1979). Growth was reported to be exponential in 2 studies with other Calanus species. However, in one of these studies, on C. marshallae (Peterson 1986), growth was not measured directly but estimated from development time and weight measurements of separate groups of copepods, and in the other study, on C. chilensis (Escribano et al. 1997), variability in the estimates of weight was very high and growth was only measured from C3 to adult.

For other species of copepods that do not have large lipid reserves, most studies have found that constant exponential growth may be more closely approached, at least during the copepodite stages (e.g. Acartia clausi: Sekiguchi et al. 1980, Klein Breteler et al. 1982; A. tonsa: Miller et al. 1977, Berggreen et al. 1988;
Centropages hamatus: Klein Breteler et al. 1982; Pseudocalanus sp.: Paffenhöfer \& Harris 1976, Klein Breteler et al. 1982; Temora longicornis: Harris \& Paffenhöfer 1976, Klein Breteler et al. 1982, 1990). It is not apparent why growth rates are reduced in later copepodite stages of copepod species that store lipids, since lipid biosynthesis has been suggested to be less costly than structural growth (Båmstedt et al. 1999). Nevertheless, for lipid-storing species, the assumption that growth is exponential from egg to adult does not appear to be valid.

Recently, it has been postulated that when lipid stores are discounted, the structural growth rate of Calanus spp. copepodites is constant for all stages (McLaren 1986). The lipid component is not part of the growth machinery of the copepod, and it increases proportionately in the older stages, so its inclusion in growth calculations should result in proportionately lower growth rate estimates for the older stages. Since $\mathrm{N}$ is not contained in stored lipids, $\mathrm{N}$ growth should be a proxy for structural growth. However, in our study we found that $\mathrm{N}$ growth rate, like $\mathrm{C}$ growth rate, was not constant but decreased with increasing stage of development in the copepodite stages. McLaren (1986) reached his conclusions by combining structural weights of formalin-preserved, field-collected copepods with estimated stage durations from Corkett et al. (1986) to estimate structural growth rates. The size of McLaren's (1986) field-collected copepods increased exponentially with increasing stage, as did ours. However, Corkett et al. (1986) assumed similar stage durations for $\mathrm{C} 1$ to $\mathrm{C} 4$ when fitting their curves, whereas our study indicated that they increased with increasing stage of development. Since stage durations increased with stage in our study, growth rates were not constant but decreased with stage. Were estimates of stage duration from our study to be applied to McLaren's (1986) data, then structural growth rate would not be constant for all stages but would show a decrease with increasing stage of development.

\section{Should secondary production of copepods be estimated from egg production rates alone?}

It has been proposed that secondary production of copepods can be estimated from the biomass of the population and measurement of the egg production rate of females alone (Kiørboe \& Johansen 1986, Berggreen et al. 1988, McLaren \& Leonard 1995, Poulet et al. 1995). The assumptions required for this approach are that egg production is equal to growth for adult females, the conditions required for growth are equivalent for all stages, and growth rates are the same for all stages. 
The assumption that egg production is equal to growth for adult female copepods may be valid at constant, high food levels. However, egg production for some Calanus species may be totally decoupled from recent feeding, being fueled by lipids accumulated during a previous season (e.g. C. hyperboreus: Hirche \& Niehoff 1996). In this situation, egg production of females would not reflect the current food conditions as would growth for the immature stages. For $C$. finmarchicus this does not appear to be important, because egg production rates decline rapidly when food is removed (Hirche et al. 1997).

In a fluctuating food environment, adult female copepods may undergo significant changes in weight so that not all growth is reflected in egg production. Hirche et al. (1997) suggested that adult female Calanus finmarchicus may undergo de-growth during periods of severe food limitation. On return to higher food after an extended period of starvation, they use freshly ingested material to restore internal structures before switching to egg production. Adult females of smaller copepods also undergo rapid changes in weight in response to their food environment (e.g. Acartia tonsa: Durbin et al. 1983, Thompson et al. 1994). The $C$ and $N$ growth rate of $A$. tonsa collected from the field and placed under high food conditions was inversely related to condition factor, such that females in the poorest condition showed the greatest growth rate (Thompson et al. 1994). When adult $A$. hudsonica females were transferred from high to low food and weight changes and egg production rates monitored, egg production was estimated to be only $33 \%$ of the total weight loss (Durbin et al. 1992).

Laboratory studies have demonstrated that the food types required for growth change as a function of developmental stage (e.g. Poulet 1977, Paffenhöfer \& Knowles 1978, Fernández 1979, Stoeker \& Egloff 1987, Berggreen et al. 1988, Campbell 1993), and field studies have shown that food limitation may affect growth of younger and older stages of copepods to varying degrees (e.g. Peterson et al. 1991, Campbell et al. 2001). In culturing studies such as ours, a mixture of different sizes of food are offered to ensure good growth. It is unlikely that in the field the food required by different stages are present in proportions such that the growth rates of all stages are equivalent.

The findings of the present study also indicate that the final assumption is not valid for Calanus finmarchicus because of a 2- to 3 -fold decrease in growth rate between $\mathrm{C} 1$ and $\mathrm{C} 4$. In addition, egg production was not equal to growth of younger stages. At $4^{\circ} \mathrm{C}$, egg production in terms of carbon was 0.05 and $0.06 \mathrm{~d}^{-1}$, while growth in carbon of nauplii and young copepodites was 0.15 and $0.19 \mathrm{~d}^{-1}$, respectively.
When growth is exponential throughout the life of a copepod, as is most closely approached in species of Acartia or other species that do not store large amounts of lipids, and when food levels do not fluctuate over short time scales, then using egg production to estimate secondary production of a copepod may be valid. However, we would argue that egg production is best used as an index of the degree of food limitation.

Acknowledgements. We thank M. Casas, P. Garrahan, A. Jacquet, and N. Mottola for help with sampling, stage enumeration, and size analysis. We are grateful to C. Ashjian, and 3 anonymous reviewers for helpful comments on the manuscript. This research was supported by the National Science Foundation (OCE9313677, OCE9632460, and OCE9806506). This is contribution number 190 of the US GLOBEC Georges Bank program sponsored jointly by NSF and NOAA.

\section{LITERATURE CITED}

Båmstedt U, Nejstgaard JC, Solberg PT (1999) Utilisation of small-sized food algae by Calanus finmarchicus (Copepoda, Calanoida) and the significance of feeding history. Sarsia 84:19-38

Belehrádek J (1935) Temperature and living matter. Protoplasma Monogr 8:1-277

Berggreen U, Hansen B, Kiørboe T (1988) Food size spectra, ingestion and growth of the copepod Acartia tonsa during development: implications for determination of copepod production. Mar Biol 99:341-352

Beyer JE, Laurence GC (1980) A stochastic model of larval fish growth. Ecol Model 8:109-132

Campbell RG (1993) Studies of feeding behavior, development, and food limitation in first feeding nauplii of the copepod Acartia tonsa (Copepoda: Calanoida). PhD thesis, University of Rhode Island

Campbell RG, Runge JA, Durbin EG (2001) Evidence for food limitation of Calanus finmarchicus production rates on the southern flank of Georges Bank during April 1997. DeepSea Res II 48:531-549

Carlotti F, Nival S (1991) Individual variability of development in laboratory-reared Temora stylifera copepodites: consequences for the population dynamics and interpretation in the scope of growth and development rules. J Plankton Res 13:801-813

Conover RJ (1988) Comparative life histories in the genera Calanus and Neocalanus in high latitudes of the northern hemisphere. Hydrobiologia 167/168:127-142

Corkett CJ (1984) Observations on development in copepods. Studies on Copepoda. II. Proceedings of the First International Conference on Copepoda, Amsterdam, 1981. Crustaceana Suppl 7:150-153

Corkett CJ, McLaren IA (1970) Relationships between development of eggs and older stages of copepods. J Mar Biol Assoc UK 50:161-168

Corkett CJ, McLaren IA, Sevigny JM (1986) The rearing of the marine calanoid copepods Calanus finmarchicus (Gunnerus), C. glacialis Jaschnov and C. hyperboreus Krøyer with comment on the equiproportional rule. In: Schriever G, Schminke HK, Shih C-t (eds) Proceedings of the Second International Conference on Copepoda, 13-17 August 1984, Syllogeus 58. National Museums of Canada, Ottawa, p 539-546 
Crawshay LR (1913) Notes on experiments in the keeping of plankton animals under artificial conditions. J Mar Biol Assoc UK 10:555-576

Deevey GB (1960) Relative effects of temperature and food on seasonal variations in length of marine copepods in some eastern American and western European waters. Bull Bingham Oceanogr Coll Yale Univ17:55-86

Durbin EG, Durbin AG (1978) Length and weight relationships of Acartia clausi from Narragansett Bay, R.I. Limnol Oceanogr 23:958-969

Durbin EG, Durbin AG, Smayda TJ, Verity PG (1983) Food limitation of production by adult Acartia tonsa in Narragansett Bay, Rhode Island. Limnol Oceanogr 28:1199-1213

Durbin EG, Durbin AG, Campbell RG (1992) Body size and egg production in the marine copepod Acartia hudsonica during a winter-spring diatom bloom in Narragansett Bay. Limnol Oceanogr 37:342-360

Durbin EG, Gilman SL, Campbell RG, Durbin AG (1995) Abundance, biomass, vertical migration and estimated development rate of the copepod Calanus finmarchicus in the southern Gulf of Maine during late spring. Cont Shelf Res 15:571-591

Escribano R, Irribarren C, Rodriguez L (1997) Influence of food quantity and temperature on development and growth of the marine copepod Calanus chilensis from northern Chile. Mar Biol 128:281-288

Fernández F (1979) Nutrition studies in the nauplius larva of Calanus pacificus (Copepoda: Calanoida). Mar Biol 53: 131-147

Green EP, Harris RP, Duncan A (1991) The naupliar development of marine calanoid copepods under high and low food conditions. Proceedings of the fourth International Conference on Copepoda. Bull Plankton Soc Jpn, Spec Vol, p 347-362

Guillard RRL, Ryther JH (1962) Studies of marine planktonic diatoms. 1. Cyclotella nana Hustedt and Detonula confervacea (Cleve) Gran. Can J Microbiol 8:229-239

Harris RP, Paffenhöfer GA (1976) Feeding, growth and reproduction of the marine planktonic copepod Temora longicornis Müller. J Mar Biol Assoc UK 56:675-690

Hart RC (1990) Copepod post-embryonic durations: pattern, conformity, and predictability. The realities of isochronal and equiproportional development, and trends in the copepodid-naupliar duration ratio. Hydrobiologia 206: 175-206

Hirche HJ (1980) The cultivation of Calanoides carinatus Krøyer (Copepoda: Calanoida) under different temperature and food conditions - with a description of eggs and nauplii. J Mar Biol Assoc UK 60:115-125

Hirche HJ, Niehoff B (1996) Reproduction of the Arctic copepod Calanus hyperboreus in the Greenland Sea - field and laboratory observations. Polar Biol 16:209-219

Hirche HJ, Meyer U, Niehoff B (1997) Egg production of Calanus finmarchicus: effect of temperature, food and season. Mar Biol 127:609-620

Kiørboe T, Johansen J (1986) Studies of a larval herring (Clupea harengus L.) patch in the Buchan area. IV. Zooplankton distribution and productivity in relation to hydrographic features. Dana 6:37-51

Klein Breteler WCM, Schogt N (1994) Development of Acartia clausi (Copepoda, Calanoida) cultured at different conditions of temperature and food. Hydrobiologia 292/293: 469-479

Klein Breteler WCM, Fransz HG, Gonzalez SR (1982) Growth and development of four calanoid copepod species under experimental and natural conditions. Neth J Sea Res 16: 195-207
Klein Breteler WCM, Schogt N, Gonzalez SR (1990) On the role of food quality in grazing and development of life stages, and genetic change of body size during cultivation of pelagic copepods. J Exp Mar Biol Ecol 135:177-189

Klein Breteler WCM, Gonzalez SR, Schogt N (1995) Development of Pseudocalanus elongatus (Copepoda, Calanoida) cultured at different temperature and food conditions. Mar Ecol Prog Ser 119:99-110

Koski M, Klein Breteler W, Schogt N (1998) Effect of food quality on rate of growth and development of the pelagic copepod Pseudocalanus elongatus (Copepoda: Calanoida). Mar Ecol Prog Ser 170:169-187

Landry MR (1975) The relationship between temperature and the development of life stages in the marine copepod Acartia clausi Giesbr. Limnol Oceanogr 20:854-857

Landry MR (1983) The development of marine calanoid copepods with comment on the isochronal rule. Limnol Oceanogr 28:614-624

Lebour MV (1916) Stages in the life history of Calanus finmarchicus (Gunnerus), experimentally reared by Mr. L.R. Crawshay in the Plymouth Laboratory. J Mar Biol Assoc UK 11:1-17

Lynch DR, Gentleman WC, McGillicuddy DJJ, Davis CS (1998) Biological/physical simulations of Calanus finmarchicus population dynamics in the Gulf of Maine. Mar Ecol Prog Ser 169:189-210

Marcus NH, Alatalo P (1989) Conditions for rearing Calanus finmarchicus (Gunnerus, 1770) (Copepoda, Calanoida) through multiple generations in the laboratory. Crustaceana 57:101-103

Matthews JBL (1966) Experimental investigations of the systematic status of Calanus finmarchicus and C. glacialis (Crustacea: Copepoda). In: Barnes H (ed) Some contemporary studies in marine science. George Allen \& Unwin Ltd, London, p 479-492

McLaren IA (1986) Is 'structural' growth of Calanus potentially exponential? Limnol Oceanogr 31:1342-1346

McLaren IA, Leonard A (1995) Assessing the equivalence of growth and egg production of copepods. ICES J Mar Sci 52:397-408

Miller CB, Johnson JK, Heinle DR (1977) Growth rules in the marine copepod genus Acartia. Limnol Oceanogr 22: $326-335$

Miller CB, Lynch DR, Carlotti F, Gentleman W, Lewis CVW (1998) Coupling of an individual-based population dynamic model of Calanus finmarchicus to a circulation model for the Georges Bank region. Fish Oceanogr 7: $219-234$

Mullin MM, Brooks ER (1967) Laboratory culture, growth rate, and feeding behavior of a planktonic marine copepod. Limnol Oceanogr 12:657-666

Mullin MM, Brooks ER (1970a) Growth and metabolism of two planktonic, marine copepods as influenced by temperature and type of food. In: Steele JH (ed) Marine food chains. Oliver \& Boyd, Edinburgh, p 74-95

Mullin MM, Brooks ER (1970b) The effect of concentration of food on body weight, cumulative ingestion, and rate of growth of the marine copepod Calanus helgolandicus. Limnol Oceanogr 15:748-755

Omori M, Ikeda T $(1984)$ Methods in marine zooplankton ecology. John Wiley, New York

Paffenhöfer GA (1970) Cultivation of Calanus helgolandicus under controlled conditions. Helgol Meeresunters 20: 346-359

Paffenhöfer GA, Harris RP (1976) Feeding, growth and reproduction of the marine planktonic copepod Pseudocalanus elongatus Boeck. J Mar Biol Assoc UK 56:327-344 
Paffenhöfer GA, Knowles SC (1978) Feeding of marine planktonic copepods on mixed phytoplankton. Mar Biol 48: $143-152$

Peterson WT (1986) Development, growth, and survivorship of the copepod Calanus marshallae in the laboratory. Mar Ecol Prog Ser 29:61-72

Peterson WT, Painting SJ (1990) Developmental rates of the copepods, Calanus australis and Calanoides carinatus in the laboratory, with discussion of methods used for calculation of development time. J Plankton Res 12:283-293

Peterson WT, Tiselius P, Kiørboe T (1991) Copepod egg production, moulting and growth rates, and secondary production, in the Skagerrak in August 1988. J Plankton Res 13:131-154

Poulet SA (1977) Grazing of marine copepod developmental stages on naturally occurring particles. J Fish Res Board Can 34:2381-2387

Poulet SA, Ianora A, Laabir M, Klein Breteler WCM (1995) Towards the measurement of secondary production and recruitment in copepods. ICES J Mar Sci 52:359-368

Runge JA (1985) Egg production rates of Calanus finmarchicus in the sea off Nova Scotia. Arch Hydrobiol Beih 21: $33-40$

Runge JA (1988) Should we expect a relationship between primary production and fisheries? The role of copepod dynamics as a filter of trophic variability. Hydrobiologia 167/168:61-71

Runge JA, Plourde S (1996) Fecundity characteristics of Calanus finmarchicus in coastal waters of eastern Canada. Ophelia 44:171-187

Runge JA, Roff JC (2000) The measurement of growth and reproductive rates. In: Harris, R, Wiebe P, Lenz J, Skjoldal HR, Huntley M (eds) ICES zooplankton methodology manual. Academic Press, London, p 401-454

Editorial responsibility: Kenneth Sherman (Contributing Editor), Narragansett, Rhode Island, USA
Sekiguchi H, McLaren IA, Corkett CJ (1980) Relationship between growth rate and egg production in the copepod Acartia clausi hudsonica. Mar Biol 58:133-138

Stoeker DA, Egloff DA (1987) Predation by Acartia tonsa Dana on planktonic ciliates and rotifers. J Exp Mar Biol Ecol 110:53-68

Tande KS (1988) Aspects of developmental and mortality rates in Calanus finmarchicus related to equiproportional development. Mar Ecol Prog Ser 44:51-58

Thompson AM, Durbin EG, Durbin AG (1994) Seasonal changes in maximum ingestion rate of Acartia tonsa in Narragansett Bay, Rhode Island, USA. Mar Ecol Prog Ser 108:91-105

Thompson BM (1982) Growth and development of Pseudocalanus elongatus and Calanus sp. in the laboratory. J Mar Biol Assoc UK 62:359-372

Uye S (1980) Development of neritic copepods Acartia clausi and $A$. steueri. II. Isochronal larval development at various temperatures. Bull Plankton Soc Jpn 27:11-18

Uye S (1988) Temperature-dependent development and growth of Calanus sinicus (Copepoda: Calanoida) in the laboratory. Hydrobiologia 167/168:285-293

Vidal J (1980a) Physioecology of zooplankton. I. Effects of phytoplankton concentration, temperature, and body size on the growth rate of Calanus pacificus and Pseudocalanus sp. Mar Biol 56:111-134

Vidal J (1980b) Physioecology of zooplankton. II. Effects of phytoplankton concentration, temperature, and body size on the development and molting rates of Calanus pacificus and Pseudocalanus sp. Mar Biol 56:135-146

Wagner, M, Campbell RG, Boudreau CA, Durbin EG (2001) Nucleic acids and growth of Calanus finmarchicus in the laboratory under different food and temperature conditions. Mar Ecol Prog Ser 221:185-197

Submitted: March 10, 2000; Accepted: January 17, 2001

Proofs received from author(s): September 25, 2001 